İSMAİL AVCI

\title{
Klasik Türk Edebiyatında Gelenekli Bir Yazım Konusu Olarak iLiM ve MAL
}

\author{
SCIENCE and WEALTH
}

As a Traditional Writing Topic in the Classical Turkish Literature

\section{Ö Z E T}

Bu çalışmada öncelikle ilim ve malla ilgili vecizelerin hangi kaynaklarda nasıl geçtiği tespit edilmiş, ardından klasik Türk şairlerinin ilim ve mala bakışı verilmeye çalışılmıştır. Tespit edilen on sekiz metnin tamamı dikkate alınarak ilmin maldan üstünlü̈̆̈̈̈ne dair vecizeler on dört başlık hâlinde belirlenmiş; Aşık Paşa, Bedr-i Dilşad, Hazîn̂ ve Sünbülzâde Vehb̂̀'nin "ilim ve mal" konulu şiirleri bir araya getirilip karşılaştırılmıştır. Yazının sonuna Hazîn̂̀'nin ilim ve maldan bahseden bugüne dek yayımlanmamış bir manzumesi ilave edilmiştir.

A N A H T A R K E L İ M E L E R

Klasik Türk şiiri, ilim, mal, Âşık Paşa, Bedr-i Dilşad, Hazînî, Sünbülzâde Vehbî.
A B S T R A C T

In this study, first of all the sources of epigrams about science and wealth have been verified and how these epigrams appeared on them has been studied. Then Turkish classical poets' perceptions on science and wealth have been analyzed. Taking in the consideration the all verified seventeen texts, the epigrams expressing that science is above wealth have been listed under fourteen titles. Âşık Paşa's, Bedr-i Dilşad's, Hazînî's and Sünbülzâde Vehbî's poems on "science and wealth" have been brought together and a comparison has been made among them. At the end of the paper Hazinî's one poem addressing science and wealth and never been published before has been added.

K E Y W O R D S

Classical Turkish poetry, science, wealth, Âşık Paşa, Bedr-i Dilşad, Hazînî, Sünbülzâde Vehbî.

\section{Giriş}

Sözlükte 'bilmek' anlamına gelen ve günümüzde 'bilgi' ve 'bilim' karşılığında kullanılan ilim, bir şeyi gerçek yönüyle kavramak, gerçekle örtüşen kesin inanç (itikad), nesneyi olduğu gibi bilmek, nesnedeki gizliliğin ortadan kalkması gibi değişik şekillerde tarif edilmiştir. Bunun yanında bilgisizliğin (cehl) karşıtı ve belli bir alana ait sistemli bilgi biriki-

* Arş. Gör., Balıkesir Üniversitesi Necatibey Eğitim Fakültesi Türkçe Eğitimi Bölümü,

Balıkesir. (ismailavci@balikesir.edu.tr). 
mini ifade eden disiplin manasında da kullanılmıştır. İlim konusu Kur'ân'da ve hadislerde sıkça vurgulanan bir konudur. Kur'ân'da ilim kavramı, vahiy veya ilahi bilgi yanında vahiy yoluyla verilen bilgi ve dünyevi bilgiyi de kapsayacak şekilde yaklaşık 750 yerde geçmektedir (Kutluer 2000: XXII/109-110; 2001: 69-76). "Hiç bilenlerle bilmeyenler bir olur mu?" (Kur'ân-1 Kerîm, 39/9), "Allah'tan ancak âlimler korkar." (Kur'ân1 Kerîm, 35/28), "Bilmediklerinizi ilim sahiplerinden sorunuz." (Kur'ân-1 Kerîm, 16/43) gibi ayetler; "Melekler, ilim talibinden memnun olarak kanatlarinı (üzerlerine) koyarlar." (...) "Âlimler peygamberlerin varisleridir."1 , "Kim ilim talep ederse, bu işi, geçmişteki günahlarına kefaret olur."2 (Canan 1991: XI/488, 494) gibi hadisler ilimle ilgili olarak hatırlanabilir. Yine, "İlim ilim bilmekdür ilim kendin bilmekdür" (Tatç1 1997: II/148), "Kişi bilmediğine düşmandır." (Ceyhan 2008: 114), "Âlimin ölümü, âlemin ölümü gibidir." (Yılmaz 2008: II/684) gibi bazı veciz ifadelerde de aynı konu dile getirilir.

Tarihte ilimler, çeşitli şekillerde tasnif edilmeye çalışılmıştır. Temelde ilimleri dinî ve felsefi olmak üzere ikiye ayıran bu tasniflerin ilk sistematik örneği Fârâbî'nin İhsâü'l-Ulûm adlı eseridir. Bundan başka, Kindî, Hârizmî, İbn Hazm, Beyzâvî, İbn Sînâ, Gazâlî, İbn Haldûn, Molla Lutfî, Nev'î, Taşköprülüzâde, Saçaklızâde ve Kâtip Çelebi gibi isimlerin ilimleri tasnif etme yolunda çalışmaları vardır. Ancak bunlar içerisinde öne çıkanı Taşköprülüzâde'nin kapsamlı tasnifidir.

Doğrudan doğruya ilmi esas alan ve ilimleri tasnif eden bu eserler yanında, genel manada ilimlerden söz eden veya sadece bazı ilimlerle ilgili bilgiler veren ya da farklı birçok konuyu ihtiva eden ancak bunun yanında ayrı başlıklarla ilim konusuna da değinen eserler de mevcuttur. ${ }^{3}$ İslami dönemin ilk ürünlerinden Kutadgu Bilig ${ }^{4}$ (Arat 1997: 31-32, 44-49)

\footnotetext{
1 Ebu Dâvud, İlm 1, (3641); Tirmizî, İlm 19, (2683); İbnu Mâce, Mukaddime 17, (223).

${ }^{2}$ Tirmizî, İlim 2, (2650).

3 Örnek olarak, Mehekkü'l-İlim ve'l-Ulemâ (Özkan 2009); Terceme-i Kitâb-ı Fevâ'ihü'lMiskiyye fi'l-Fevâtihi'l-Mekkiyye (Yağmur 2007), Nazmu'l-Ulûm (Özfırat 2006) gibi eserler verilebilir.

4 "İnsanoğlunun Değerinin Bilgi ve Akıldan Geldiğini Söyler" ve "Bilgi İle Aklın Meziyet ve Faydaların Söyler" bölümleri.
} 
ve Atabetü'l-Hakayık'tas (Arat 1992: 47-50), Garib-nâme (Yavuz 2000: II/2/739-767), Murâd-nâme (Ceyhan 1997: I/527-532; II/533-540, 540-542, 550-616), Tazarru'-nâme (Tulum 2001: 110-112), Hayriyye9 (Kaplan 2008: 197-201), Lutfiyye ${ }^{10}$ (Beyzâdeoğlu 1996: 36-38), Cilâ' ül-Kulûb ${ }^{11}$ (Özkan 1990: 244-246), Kuddûsî Divanı ${ }^{12}$ (Doğan 2002: 252-253, 312) ve daha birçok manzum veya mensur eserde ilmin fazileti, ilim öğrenmenin ve öğretmenin önemi, bilginin insana kattığı değer konusu çeşitli açılardan işlenmiştir. İlmi doğrudan ya da dolaylı olarak ele alan bu çalışmalarda aynı zamanda, "ilim ve mal" konusu da zaman zaman üzerinde durulan hususlardan biri olmuştur.

\section{1. İlim ve Malın Mukayese Edildiği Bazı Metinler}

Çeşitli eserlerde karşımıza çıkan ilim ve malın mukayesesine dair metinlerin kaynağı, Hz. Ali'yle ilgili anlatılan bir hikâyedir. Cesareti ve kahramanlığının yanı sıra ilmi ve irfanıyla da tanınan Hz. Ali'nin ${ }^{13}$ bir

5 "Bilginin Faydası ve Bilgisizliğin Zararı Hakkında" bölümü.

6 "Bişinçi Dâsitân Onunçı Bâbdan Beyân İder Kim 'İlm Mâldan Efdaldür Bil Kim Hazret-i Risâlet 'Aleyhi's-Selâm 'Alî'ye Kerrema'l-lâhu Vechehu Buyurdı Ki 'Ene Medînetü'l- 'Ilmi ve 'Aliyyün Bâbuhâ' Çün Havâric Bu Hadîsi İşitdiler Hased İltüp On Kişi İttifâk İtdiler Ki 'Alî'den Su'âl İdeler Ki 'İlm Efdal Midür Ya Mâl Bir Bir Varup 'Alî'ye Su'âl İtdükleri ve Cevâbın Beyân İder" bölümü.

7 "Bâb-ı Bîstüheftüm Der Sitâyiş-i Dâniş ve Ehl-i Dâniş ve Hasâyil-i Îşân", "Der Hasâyil-i 'Âlimân", "Der Tafdîl-i 'İlm Ber-mâl" ve "Bâb-ı Bistünühüm Ender Taksîm-i 'Ulûm..." bölümleri.

8 "İşâret-i 'İlm" bölümü.

9 "Matlab-ı Dâniş-i Envâ'-ı 'Ulûm" bölümü.

10 "Der-Fezâil-i 'İlm-i Şerîf" bölümü.

11 "Ikd-ı Nûjdehüm Der Menâyih-i İktisâb-ı ‘İm ü Kemâl ve Medâyih-i Tertîb-i Mukaddimât-ı Kesb ü İştigâl fi'l-eyyâm ve'l-leyâl" bölümü.

${ }^{12}$ Biri on üç, diğeri on dört beyitli iki gazel.

13 "Hz. Ali, yüksek insani ve ahlaki vasıflarıla İslâmiyetin örnek şahıslarından biridir. İslam tarihi boyunca Hz. Muhammed'den sonra adından en çok bahsedilen İslam büyü̈̆̈̈̈ü̈r. Hz.

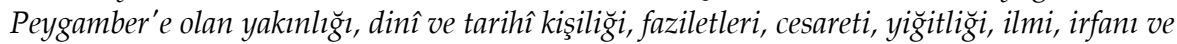
veliliği ile Şark-İslam edebiyatlarındaki her mezhep, tarikat ve meşrepten şairlerin sevgisi ve ilgisine mazhar olmuştur. Türk edebiyatında da ona geniş yer verilmiş, onun kahramanlğını, faziletlerini, ilmini, irfanını ve veliliğini en iyi ifade edenler Divan şairleri olmuştur. Divan şairlerinde Hz. Ali'ye karşı derin bir sevgi ve içten bir bağlllık sezilmektedir. Şairler, müstakil ve müşterek olmak üzere onun hakkında birçok na't yazmışlardır. Divan şiirinde 
anlamda "ilim ve mal"ın insan hayatındaki yerine işaret eden düşüncelerinin özeti durumundaki bu hikâyeye göre Hz. Muhammed, "Ben ilim şehriyim, Ali de onun kapısıdır."14 sözünü söyleyince Haricîler Hz. Ali'yi kıskanmışlar ve onun ilmini sorgulamak istemişlerdir. Haricîlerden on kişinin ilim ve malla ilgili sordukları aynı soruya Hz. Ali'nin nedenleriyle

Hz. Ali, bazen ilk üç halifeyle veya oniki imamla birlikte, bazen sadece kendisi için müstakil yazılan na'tlarda, bazen Hz. Peygamber'e yazılan na'tlarm son bölümlerinde, bazen de kaside ve gazellerin münferit beyitlerinde "kahramanlı, cömertlik, ilim, irfan ve velayet timsali" olarak anılmış, bu seçkin vasıflarıyla çeşitli teşbih, telmih ve mukayeselere konu edilerek övülmüştür. (...) Divan şairleri, Hz. Ali'nin ilim sahibi olmasını, sözlerinde ve uygulamalarında ilmi üstün tutmasın ve ilim tahsiline önem vermesini takdir etmişler, bu özelliklerinden dolayı onu ilim ve irfan abidesi olarak tavsif etmişlerdir." (Güftâ 2002: 69-70).

${ }^{14}$ Tirmizî (Menâkıb 20, [3969])'de geçen bu hadisin sahih olmadığına dair bazı kayıtlar vardır. Hz. Ali'den veya dört halifeden bahseden müstakil eserlerde, mesnevilerin dört halifeye övgü için ayrılan kısımlarında, ilmin konu edildiği bazı eserlerde, divanlarda bu söz sıkça geçer. Birkaç örnek:

Eytdi 'ilmüñ şehri benven kamusı

İlla bu şehrüñ 'Alî'dür kapusı (Âşık Paşa) (Yavuz 2000: II/2/743)

Benüm şehr-i 'ilim kapu 'Alî'dür

İçi nûr-1 hidâyet toptolıdur (Mürîdî) (Kılıç 2005: 118)

Didi iki cihânuñ sevgülüsi

Benem şehr-i 'ulûm oldur kapusı (Tebrizli Ahmedî) (Ayan 1996: 10)

Dil ü cândan diyüp durur peyam-ber

Ki şehr-i 'ilm ben oldum 'Alî der (Cem Sultan) (İnce 2000: 61)

Nebî medîne-i 'ilm oldu bâbı Şâh-1 Necef

O dergehüñ itiyem ol kapuda derbânem (Hayâlî Bey) (Tarlan 1992b: 208)

Bula gör eyle medîneye vusûl

Ki kapusı ola damad-1 Resûl (Nâbî) (Kaplan 2008: 198)

İlim ve mal konusuyla ilgili olarak şu hadis de hatırlanabilir:

"Dünya dört kişi içindir: Bir kul vardır, Allah kendisine mal ve ilim vermiştir de kul, malı hususunda Allah'tan korkmakta, (mal ve ilmi kullanarak) sılayırahim yapmakta, (mal ve ilimde) Allah'ın hakkı olduğunu bilmektedir. İşte bu kimse en faziletli bir makamdadır. Bir kul vardır, Allah ona ilim vermiştir, mal vermemiştir, ama iyi niyetlidir ve 'Malım olsaydı onu falan kişi gibi (hayırda) harcardım.' der. İşte bu kimse niyetindekini yapmış gibi sevaba nail olur, ikisi de eşit şekilde ücrete konar. Bir kul vardır, Allah ona mal vermiştir, fakat ilim vermemiştir. Malın cahilane harcar. Malı hususunda Rabb'inden korkmaz. (Cimriliği, cahilliğgi sebebiyle) malıyla sılayırahim yapmaz, malında Allah'ın da hakkı olduğunu hiç düşünmez. İşte bu kimse, mertebelerin en düşüğündedir. Bir kul vardır, Allah ona ne ilim ne de mal vermiştir, ama 'Ĕ̆ger malım olsaydı onunla falan kimsenin yaptıklarım ben de yapardim.' der. Bu da niyetiyle muamele görür. Niyet ettiği kimsenin vebalini aynen elde eder." Tirmizî, Zühd 17, (2326); İbni Mâce, Zühd 21, (4228) (Canan 1991: XV/175-176). 
birlikte verdiği farklı, veciz cevapları içeren ve bu on kişinin doğru yolu bulmasıyla son bulan hikâyenin, özellikle ilimden söz edildiğinde, mala karşı ilmin niçin tercih edilmesi gerektiği hususu işlenirken anlatıldığı görülür. Ancak bazı eserlerde bu konu bir hikâye olarak anlatılmamış, sadece ilmin maldan üstünlüğü birkaç madde hâlinde ve Hz. Ali'yle bir bağ kurulmaksızın verilmekle yetinilmiştir. Kaynaklara bakıldığında sözü edilen konunun 11. asırdan 19. asra kadar özellikle ilimden, Hz. Ali, dört halife ya da evliyadan bahseden eserlerle dinî, ahlaki konulu eserlerde, nasihatnamelerde ve edebî eserlerde çokça yer aldığı görülür. Tespit edilebilen bazı eserlerde bu konu şöyle geçmektedir: ${ }^{15}$

Şerif Radî (öl. 406/1015)'nin hazırladığ1 Nehcü'l-Belâga adlı eserde, Hz. Ali'nin Kûfeli Kümeyl b. Ziyâd'a ilim ve malla ilgili olarak "Akıl, Bilgi" başlıklı bölümde şöyle söylediği yazılıdır:

"Ey Kümeyl, ilim maldan hayırlıdır; ilim seni korur, sense malı korursun. Mal, vermekle azalır, ilim öğretmekle çoğalır. Mal sahipleri malın zevaliyle zeval bulup giderler. Ey Ziyâdoğlu Kümeyl, bilgiyi elde etmek, âdetâ dindir ki Allah'a onunla yol bulunur. İnsan, yaşarken onunla tâat elde eder; ölümünden sonra da iyilikle, hayırla anılır. İlim hâkimdir, malsa hüküm altındadır, mağluptur. Ey Kümeyl, malları hazinelerde biriktirenler, diriyken ölmüşlerdir; bilginlerse dünya durdukça yaşarlar. Kendileri yok olup gitmişlerdir, fakat eserleri yüreklerde mevcuttur." (Gölpınarlı trz: 414).

Ebu Nuaym el-Isfahânî (öl. 430/1038)'nin Hilyetü'l-Evliyâ ve Tabakâtü'l-Asfiyâ adlı eserinde, Nehcü'l-Belâga'da da geçtiği şekliyle Hz. Ali'nin Kümeyl b. Ziyâd'a öğüdü olarak verilen kısımda konu şu şekildedir:

“... İlim maldan daha değerlidir. İlim seni korur, malın koruyucusu ise sensin. İlim, onu işledikçe, onunla amel ettikçe daha da artar, fakat mal harcadikça tükenir. Âlimi seomek dindendir. İlim âlime yaşarken tâat kazandırır, öldükten sonra hayırla anılmasını sağlar. Mal biriktiren ise malla birlikte yok olur, adı da kalmaz. Mal yı̆̆anlar diriyken bile ölü gibidirler. Ulemanın ise dünya durdukça adı anılır. Âlimler ölüp gider, ama menkıbeleri gönüllerde yaşar. İlim

${ }^{15}$ Metinlerin tespiti konusunda yardımını gördüğüm hocam Prof. Dr. Âdem Ceyhan'a ve fikirlerinden yararlandığım hocam Prof. Dr. Ömür Ceylan'a teşekkür ederim. 
ancak, ona sahip olanların ölüp tamamen yok olmasıyla ortadan kalkar..." (Sahabeden Günümüze... 1995: 199-200).

Kümeyl b. Ziyâd'la ilgili aynı rivayet İmam Gazâlî (öl. 505/1111)'nin İhyâu Ulûmi'd-Dîn adlı eserinde de geçer:

"Kümeyl, ilim maldan hayırlıdır. Çünkü ilim seni, sen ise malı korursun. İlim hâkim, mal mahkûmdur. Mal harcanmakla eksilir, ilim sarfiyatla artar." (Gazâlî 1998: I/17)

Ziyaroğullarından (316/928-470/1077) Emîr Unsurü'l-Maâli Keykâvus tarafından 475/1082 yılında yazılan ve Mercimek Ahmed bin İlyas tarafından 835/1431'de II. Murad (1421-1451)'ın isteğiyle Farsçadan Türkçeye çevrilen Kabus-nâme'nin "Ata ve Ana Hakkın Yerine Getirmeyi Beyan Eder" başlıklı bölümünde aynı konu şöyle geçmektedir:

"Bir dahi ey cigergûşem, cehdeyle ki tanlacak durduğun vakit senden yukarılara bakıp melûl olma; senden aşağılara bak sevin. Ta ki şakirlerden olasın. Ve dahi cehdeyle ki eğer mala yoksul olup akıl ve danişte bay olasin. Zira ki akıl ve daniş mal ve menalden yeğdir. Anın için ki akıl ve bilü ile mal hâsıl etmek olur ve lakin mal ile akıl ve bilü hâsıl etmek olmaz. Ve bir dahi bu kim mal cahilden gitmeye imkân vardır, amma akıl ve bilü kişiden gitmez. Ve hem mala uğrudan ve haramiden ve oda yanmaktan ve buna benzer nesnelerden ziyan vardır ve lakin akıl ve bilüye hiç ziyan yoktur. İmdi ey ciğergûşem ağer aklın ve bilün var ise hüner öğren ki akıl ve bilü olsa ve hüner olmasa ol bir tene benzer ki yalıncak ola ve bir surete benzer ki canı olmaya. Filcümle çünki aklın ve bilün ve hünerin oldu, zinhar edeb dahi elden koma. Nitekim Arap aydur: El-edebü suretü'l-akli, yani edep aklın görküdür." (Gökyay 2006: 44).

Karahanlılar devri İslam fakihleri arasında gösterilen ve Türkistan'ın Zernûc beldesine nispet edilen Burhanuddin ez-Zernûcî (öl. 593/1196'dan önce)'nin Ta 'lîmü'l-Müteallim adlı ilim, ilmin değeri, ilim öğrenmenin önemi, hoca öğrenci ilişkisi... gibi konuların işlendiği eserinde ise ilim ve mal konusu Hz. Ali'yle Haricîler arasında geçen bir hikâye olarak şöyle anlatılır:

"Haricîlerle Hz. Ali (r.a.) arasında şu tartışma geçer: Haricîler Hz. Ali'ye sorarlar, 'Ya Ali ilim mi üstün yoksa mal mı?'Hz. Ali (kerremallahu vecheh) 'İlim daha üstündür' diye cevap vermiş, fakat delil istemeleri karşısında ilmin üstünlüğ̈̈̈nü şu şekilde ortaya koymuştur: 
'İlim maldan üstün, çünkü ilim seni korur, hâlbuki sen malı korursun.' (...)

'İlim harcandıkça artar, mal harcandıkça azalır.' (...)

'İlim sayesinde düşmanlar dost olur, fakat mal böyle değildir.' (...)

'İlim dünyadan uzaklaştırıp ahirete yaklaştırır. Mal ise ahiretten uzaklaştırup dünyaya meylettirir.' (...)

'İlim sahibi öldü̈̆̈̈̈ zaman sahibinin mülkiyetinden çıkmaz, fakat mal kişi öldü̈̆̈̈ zaman biter.' (...)

'İlim sahibine sirayet eden bir nurdur. Mal ise buna muhaliftir.' (...)

'İlim Allah'ın kelamından çıkar, mal ise topraktan çıkar.' (...)

'İlim peygamberlerin sevgilisidir. Mal ise Nemrud, Firavun, Haman ve Karunlarm sevgilisidir.' (...)

'İlim kendine hizmet edilendir. Mal ise hizmet edendir.' (...)

'İlim ruhun gıdasıdır. Mal ise cesedin gıdasıdır. Korku anlarında ilim, sahibine arkadaş, dost olur. Mal ise aksine korku, ürküntü verir. Yolculuk sırasında ilim insanın arkadaşıdır. Mal ise yolculukta senin düşmanın olur. Yalnız başına ilim tatsız da olsa kurtulmana sebep olur. Fakat mal böyle değildir. İlim peygamberlerin mirasıdır. Mal ise eşkıyanın mirasıdır. Kıyamet gününde ilmin hesabı yoktur. Fakat malın helal ise hesabı, haram ise azabı vardır. İmin sahibi şefaat edecek, malın sahibi ise şefaat edilecektir. İlim sahibi asla unutulmaz, fakat mal sahibi unutulur gider. İlim kalbi nurlandırır, mal ise kalbi karartıp katılaştırır. İlim sahibi Allah'a kulluğu, mal sahibi ise ilahlık iddiasinda olduğunu iddia eder.'" (ez-Zernûcî 1996: 70-72).

Kime ait olduğu ve ne zaman yazıldığı belli olmayan, ancak içerik olarak Ta 'lîmü'l-Müteallim'e çok benzeyen Minhâcü'l-Müteallim'de de ilim ve malın karşılaştırıldığı bir bölüm vardır. Burada ilmin maldan üstünlüğü yedi madde hâlinde sıralanır, ancak diğer eserlerden farklı olarak ilmin maldan üstünlüğüne dair cümleler Hz. Ali'nin değil, Abdullah b. Mes'ud'un dilinden verilir. Bundan hemen önce de aynı konuyla ilgili bir rivayet yer alır:

"İlim hazinelerden daha üstündür. Çünkü hazinelerden harcanınca eksilirler, ilimse harcanmakla çoğalır. İlim, sahibini (ehlini) her türlü afetten korur, mal ise sahibini afetlere sokar. İlmin örneği yol üzerindeki kandil örneği gibidir. 
Yoldan gidip gelenler onun ışı̆̆ından istifade ederler, aydınlanırlar. Fakat kandilin ışı̆̆ı asla eksilmez.

Bil ki insanlar ilim ile maldan hangisinin daha üstün olduğu hususunda görüş ayrllı̆̆ına düşmüşlerdir. Biri demiş ki ilim maldan daha üstündür, diğgeri ise mal ilimden daha üstündür demiş. Bu şekilde tartışmıslar, nihayet Abdullah b. Mes'ud'a bu konuyu sormak üzere bir elçi göndermişler. Adam gidip tartışma konusunu ona sormuş. İbn-i Mes 'ud şöyle buyurmuş: Bil ki ilim yedi yönden maldan daha üstündür:

1. İlim peygamberlerin mirasıdır, mal ise firavunların, eşkıyanın mirasıdır.

2. İlim, sahibini korur, oysa malı sahibi korur.

3. Malı Allah sevdiğine de sevmediğine de verir, fakat ilmi sadece sevdiklerine verir.

4. İlim vererek ve harcanarak eksilmez, mal ise harcanarak ve vererek eksilir.

5. İlim sahipleri ölmezler, kıyamete kadar da amelleri kesilmez, ebedî olarak ilmi kendileri ile beraber gider. Mal sahibi ise ölür, ameli kesilir, malı başkalarına kalır.

6. İlim sahibi kabirde azaba uğramaz, cesedi çürümez. Mal sahibi ise kabirde azaba uğrar, cesedi çürür.

7. Mal sahibi klyamet gününde her bir dirhemi nereden kazanıp nereye harcadığından sorulacak, bundan dolayı hesaba çekilecek. İlim sahibine ise öğrendiğ $i$ her bir meseleden dolayı bir derece, her bir harften dolayı bir sevap, Kur'an'ı abdestsiz okursa onun her bir harfine karşıllk on sevap verilecek, eğer namaz dışında abdestli okursa her harfine karşılık yüz sevap verilecek, eğer namazda okursa her harfine karşılık bin sevap verilecek." (Minhâcü'l-Müteallim trz.: 3334).

Muhammed bin Ebû Bekr el-Usfûrî (öl. 660/1261?)'nin Arapça olarak kaleme aldığ Şerh-i Hadîs-i Erbaîn adlı eserinde ilim tahsil etmenin öneminden bahseden dördüncü hadisten sonra anlatılan ilim ve malla ilgili hikâye ise Ta 'limü'l-Müteallim'dekine benzer şekilde anlatılmıştır. Burada dikkati çeken husus, Hz. Ali'nin kendisine ilim ve maldan hangisinin daha üstün olduğunu soranlara, 'Ĕğer bana bu soruyu sormaya devam etmiş olsaydınız yaşadığım sürece her birinize başka başka cevap verirdim.' şeklindeki ilim konusunda kendine güvenini ortaya koyan cümlesidir. İlim 
ve malın mukayesesine dair Hz. Ali'ye atfedilen cümleler kırk hadis şerhinde şöyle sıralanmıştır:

"İlim peygamberlerin mirasıdır. Mal ise Kârûn, Şeddâd, Firavun ve benzerlerinin mirasıdır. (...)

İlim seni korur. Maln ise sen korursun. (...)

Mal sahibinin birçok düşmanı vardır. İlim sahibinin ise pek çok dostu vardir. (...)

Mal harcamakla azalır. İlim ise harcamakla çoğalır. (...)

Mal sahibi cimrilik ve alçaklıkla çağrılır, ilim sahibi ise azamet ve şerefle çă̆rilır. (...)

Mal hirsizlıktan korunur, ilim ise korunmaz. (...)

Mal sahibi kıyamet günü hesaba çekilecek, ilim sahibi ise kıyamet gününde şefaat edecek. (...)

Mal zamanla yok olur, ilim ise yok olmaz ve çürümez. (...)

Mal kalbe kasvet verir, ilim ise kalbi nurlandirur. (...)

Mal sahibi malına güvenerek tanrilık iddia eder. İlim sahibi ise kulluk davasindadır." (Durak 2002: 14-16).

Telif ve tercüme eserleriyle döneminin önemli simaları arasında yer alan İznikli Mûsâ bin Hâc1 Hüseyin (öl. 838/1434)'in Münebbihü'r-Râkidîn (Uyurları Uyandurucı) adlı on beş bölümden oluşan eserinin "Beyânu Fazîleti'l-'Illm" başlığı altında ilimin maldan üstünlüğü şu şekilde anlatılır:

“...'ilm çokaldup kemâle erişdürmek hayırlıdur mâl çokaldup kemâle erişdürmekden hoz sen saklarsin dahı anuñ sebebinden dünyâda ve âhiretde belâlardan kurtılmazsın ve dahı 'ilm pâzişâh gibi hâkimdür ve mâl râ 'iyyet gibi mahkûmdur pes sultânıla râ'iyyet arasında fark ne mikdârısa 'ilmile mâl arasinda dahı ol deñlü kıyâs kıl belki dahı ebter ve dahı mâl virmegile ve harc kılmagıla noksân olur ammâ 'ilm verüp harc etmegile karşu ziyâde olur imdi bu zâhirdür kim vermegile eksilenden vermegile ziyâde olan hayırlıdur ve dahı Ebu'l-esved eydür râziye Allâhu 'anhu hîç bir nesne yok ol 'ilimden 'azîzrak ola görürsin kim bu pâzişâhlar halk üzerine hâkimlerdür ammâ 'âlimler 'ilmile pâzişâhlar üzerine hâkimlerdür İbni 'Abbâs râziye Allâhu 'anhu eydür Hak Ta'âlâ Süleymân peygâmberi 'aleyhi's-selâm muhayyer kıldı 'ilmile mâlı mülk 
ortasında ya 'nî Hak Ta âlâ dedi ki yâ Süleymân dilerseñ 'ilm ihtiyâr eyle saña 'ilm vereyin dilerseñ mâl u memleket ihtiyâr eyle an vereyin Süleymân 'aleyhi's-selâm 'ilmi ihtiyâr kıldı Hak Ta 'âlâ 'ilm ve mâl u memleketi cümlesin bile verdi..." (Yavuzarslan 2002: 463).

Mehmet Ali Aynî de Türk Ahlakçıları adlı eserinde "Hacı Hüseyinoğlu İznikli Ebulfazl Musa" başlığıla müelliften ve Münebbihü'r-Râkidîn'den bahseder ve ilmin maldan üstünlüğünü İznikli Musa'dan nakille özet olarak verir (Aynî 1993: 53).

15. asır müelliflerinden Amasyalı Ali b. Hüseyin (öl. 875/1470)'in Tarîku'l-Edeb adlı eserinde "İlmüñ Fazîletin Dahi Edeblerin Bildürür" başlı̆̆ altında ilim ve malın karşılaştırıldığı bölüm şöyledir:

"Zîrâ 'ilm taleb itmek sâ'ir ferâyizden bir farzdur ki lâzimetü'l-ikâmedür ve iki cihânuñ şerefi anuñladur. Zîrâ ki kişi dünyâdan intikâl idüp gider olduğu hâlde mecmû'-ı ömri hâsılı mâl ü menâl ve nakd ü cins ve esbâb u emlâk ki ma'bûd ve maksûd idinmiş, divşirüp yığmış idi, hep dökülür kalur. Birisi kendüyle gitmez ve 'ilm senüñle bile gider ve ehl ü 'yyâl ve hadem ü haşem ki mahbûb u ma ş̧̂ิk idinmişdi. Öldüğ̈̈̈nden soñra bir lahza yaturmazlar belki 'aceleyle techîz ü tekfin idüp makbereye gönderürler. Birisi buçuk sâ 'at yoldaş olup bile varamaz ve 'ilm refîk yoldaşdur, şefikdür ayrlmaz senden ve mâlı uğru ve harâmî alur ve telef olur, 'ilmi kimse ne uğrulayubilür ve ne gazabla alıbilür. Mâlı sâhibi saklar ve 'ilm ıssını hıfz ider ve mâlı harc itdüğ̈ünce eksilür ve 'ilm tasarruf kıldu ğunca artar." (Şeker 2002: 162-163).

15. ya da 16. asırda Bâlî tarafından Farsça bir eserden tercüme edilen Bahru'n-Nesâyih, adından da anlaşılacağı üzere bir nasihat kitabıdır ve eserin ikinci babı "İlm-i Dâniş Beyânındadur" başlığını taşır. Bu bapta ilim ve mal konusundaki vecize şu şekilde geçmektedir:

"Ehl-i dâniş dimişlerdür: Mâldan 'ilm yegdür. Egerçi mâl ve dünyânuñ metâ'- mütenevvi'ası ve zehârifi ve ârâyişi göñüllerde mahbûb düşmişdür ki mâl bezl itmegile dünyâda âsâyiş ü refâhiyyetile 'yş̧ ü 'işret ve sürûr u râhat yüz gösterür ve hem mâl bezl itmegile âhiret âbâd idüp yarnngı güniçün hayrıla zahîre idinmege kâbildür. Bu cümlesiyle 'ilmüñ mâl üzerine niçe fazîleti vardur. Beşini zikr idüp bâkîsini terk idelüm.

Evvelki oldur kim: Selâtîn-i rûzigâr ve her pâdişâh-ı kâmkâr ehl-i dânişi mu'teber dutup 'ulemâyı muhterem ve mükerrem dutmakda mübâlagayıla 
ri'âyet itmegi kânûn-ı melikânelerine muvâfik göregelmişlerdür ammâ mâl-dâr tâ'ifenüñ hâli bunuñ 'aksincedür. Mâlı çoklar mâlları saklamagıçun pâdişâhlar belki beglerüñ hizmet-kârlarma hizmet idegelmişdür.

İkinci: 'Ulemâ 'ilm vesîlesiyle ekser hatarlardan masûn ve mahfûz ve belâlardan fârig eymenlerdür. Mâllu kişilerüñ hâli bunuñ 'aksincedür. Başlarn ve cânlarn mâl uctndan hatar ma'berlerinden ve âfet mi 'râzlarından hâlî degildür. Mukîmiken bî-huzûr ve bî-âsâyiş geçerler, müsâfir olıcak el- 'iyâzü bi'llâh.

Üçinci: Mâl ki isrâf üzerine ifrâtıla harc olınsa kûh-ı Kaf olursa tîz fenâ bulup tükenür, 'ilm ne kadar ziyâde harclansa ol kadar artar.

Dördinci: Eger vakâyi'-i rûzigârdan bir hâdise mâl bol bulursa mâla fenâ irüp sâhib-i mâl müflîs dervîş olur. Ol meşakkatler ki mâl hakkında çekmişdür zâyi' olur. 'İmü̃̃ hâli bunuñ 'aksidür ki 'ilm 'âlimden hergiz ayrlmaz eger cemî'-i 'âlem cem' olsalar ki bir mes'ele 'âlimü̃ hâtırmdan mahv ideler mümkin degüldür.

Beşinci: 'İlm ki var gâlibâ mûcib-i fevz ü necât olur. Âhiretde mâl ekser sebeb-i 'azâb ve 'ukûbet olur ve âlimün hîç mâl olmasa 'ilm vesîlesiyle mâl hâsıl idebilür ammâ mâlı olup 'ilmi ve kifâyeti olmayanuñ mâlıla 'ilm hâsıl itmesi müte 'azzirdür." (Birlik 2001: 56-57; Er 1998: 116-117) ${ }^{16}$

16. asır müelliflerinden Şemseddin Sivasî (öl. 1006/1597)'nin Menâkıb-ı Çehâr-Yâr-ı Güzîn adlı eserinin Hz. Ali'den bahseden bölümünde "Menkıbe" başlığıyla ilim ve malın konu edildiği hikâye de Ta 'lîmü'l-Müteallim ve Şerh-i Hadîs-i Erbaîn'de anlatılanla hemen hemen aynıdır. Burada Hz. Ali'nin cevapları şöyle verilmiştir:

"İlim peygamberlerden (as) mirastır. Mal Kârûn, Firavun ve Hâmân'dan mirastır. (...)

İlim efdaldir, çünkü ilim sahibini saklar, malı ise sahibi saklar. (...)

İlim efdaldir, çünkü mal sahibinin düşmanı çoktur, ilim sahibinin ise dostu çoktur. (...)

İlim efdaldir, çünkü mal sarf edilince eksilir. İlim sarf edilince artar. (...)

${ }^{16}$ Her iki çalışma da farklı nüshalara dayanmaktadır. Çalışmalarda mütercim hakkında bir bilgiye de ulaşılamadığı belirtilmiştir. Dilek Birlik'in çalışmasında eserin yazılış yılı 871/1466 (s. 10), Âdem Er'in çalışmasında ise 961/1553 (s. 8) olarak verilmiştir. 
Mal sahibini cimri diye, ilim sahibini ise büyük isimlerle çă̆̆ırılar. (...)

Mal eşkiyadan saklanır, ilim eşkiyadan saklanmaz. (...)

Mal durmakla zayi olur. İlim durmakla zayi olmaz. (...)

Mal kalbi karartır, ilim ise nurlandırır. (...)

Mal sahibi, çok malı sebebiyle ilahlık davasında bulunur. İlim sahibi böyle bir davada bulunmaz. (...)

Mal kalbin katılaşmasına sebep olur, ilim rahmete sebep olur. ${ }^{117}$ (Kargill ve Yolcuoğlu 2005: 270-271).

Taşköprülüzâde Ebulhayr İsameddin Ahmed Efendi (öl. 968/1561)'nin Miftâhü's-Saâde ve Misbahü's-Siyâde adıyla Arapça olarak yazdığ1 ve oğlu Taşköprülüzâde Muhammed Kemâleddin Efendi (öl. 1030/1620)'nin Mevzûâtü'l-Ulûm adıyla Türkçeye çevirdiği, ilimlerin tarifi ve tasnifi konusunda en kapsamlı, en derli toplu bilgiyi veren eserde ilim ve mal konusu "İlmin Fazileti" başlığıyla yedi madde hâlinde şu şekilde geçmektedir:

"Allah'ın galib arslanı hazreti Ali ibni Ebî Tâlib (kerremallahü vecheh) buyurdu: İlim maldan yedi yönüyle üstündür:

1. İlim peygamberler mirası, mal firavunlarn mirasidır.

2. İlim vermek ile azalmaz, mal vermekle azalır.

3. İlim korumaya, bekçiye muhtaç değil, malı ise beklemek, korumak lazımdır. Bilakis ilim sahibini korur, onu günah ve yasaklardan men eder.

4. Âlim ölürse ilmi kendiyle kabre girer, mal sahibi ölünce malını dünyada burakır gider.

5. İlim yalnız mümine nasip olur, mal mümine ve kâfire nasip olur.

6. İnsanlar din işlerinde âlime muhtaçtırlar, ama mal sahibine kimse muhtaç olmaz.

7. İlim, sahibini stratı geçmekte takviye edip huzura kavuşmă̆a sebep olur. Mal ise sahibini stratı geçmekten men eder." (Taşköprülüzâde Ahmed Efendi 1975: I/27).

\footnotetext{
${ }^{17}$ Sivasî, hikâyenin sonunda "Mişkâtü'l-Envâr kitabından alındı." diyerek bu hikâyenin Gazâlî'nin Mişkâtü'l-Envâr (İmam-ı Gazâlî 2007) adlı eserinden alındığını belirtmiştir. Ancak adı geçen eserde ilim ve malla ilgili bazı cümleler olmakla birlikte böyle bir hikâye ya da ilim ve malın karşılaştırıldığı bir kısma rastlanamamıştır.
} 
Edebiyatımızdaki ilk çocuk dergisi olarak gösterilen ve 1869-1870 yıllarında 49 sayı olarak çıkan Mümeyyiz dergisinin 14. sayısında yayımlanan "Bilmek ve Bilmemek" başlıklı yazıda bilmenin, dolayısıyla ilmin önemi ve buna mukabil malın ilme nazaran durumu şöyle verilir:

“... ilim sahibi olanların kendisine faydasının dokunduğu gibi etrafındakilere de faydası dokunur. Nihayet bir adam dünya kadar mal sahibi de olsa onu bir günde harcayıp yok edebilir. Fakat ilim öyle değildir. Harcadıkça artar. Bir insan ömrü hayatında biriktirdiği malın evlatlarının ilim ve hüner kazanması için harcamazsa öldükten sonra malın dünyada bırakıp gideceğgi için üzülür. Fakat evlatları onun vefat ettiğ i gün matem yerine bayram yaparlar. Bu maldan terbiye edilmemiş evlatlar da hayır görmez. Bunun aksine bir adam malını evlatlarının iyi yetişmesi ve hayır işlerine harcar ise hem evlatları arkasından hayır duâ ettirecek işler yaparlar hem de hayır yaptığı kişiler arkasından hayır duâ ederler. Böyle bir adam vefat ettiğinde cümle âlem matem eder ve arkasindan Fatiha okur. Kısaca ilim olmadan akçenin değeri yoktur. İnsanın öldükten sonra kendisine yarayacak olan şeyin ilim olduğu göze çarpmaktadır. Tükenmeyen, harcadıkça artan bu hazine, insana ahiret hayatında da fayda sağlamaktadır." (Arslan 2007: 48).

Buraya kadar olan metinlere, ileride üzerinde durulacak olan 14. asırdan Âşık Paşa (öl. 733/1332)'nın Garib-nâme, 15. asırdan Bedr-i Dilşad (doğ. 807/1404-5, öl. ?)'ın Murad-nâme, 16. asırdan Hazînî'nin Şerh-i Hadîs-i Erbaîn tercümesi (trc. 930/1524) ve 18. asırdan Sünbülzâde Vehbî (öl. 1222/1808)'nin Lutfiyye adlı manzum eserleri de katıldığında, ilim ve mal konusunun hemen her asırda farklı eserlerde ortaya çıtı̆̆ 1 ve konunun ilimle ilgili olarak önemine binaen bir devamlılık gösterdiği rahatlıkla söylenebilir. Tespit edilebilen dördü manzum on dördü mensur toplam on sekiz metinden dokuzunda ilim ve malın mukayesesi, Hz. Ali'yle ilişkilendirilerek yer almıştır. Bunlardan beşinde konu Hz. Ali'yle Haricîler arasında geçen bir olayın hikâyesi olarak anlatılmış, dördünde ise $\mathrm{Hz}$. Ali'nin nasihati şeklinde verilmiştir. Bir metinde ise kendisine soru sorulan ve ilmin maldan üstün olduğunu söyleyen Hz. Ali değil Abdullah b. Mes'ud'dur. İlmin maldan üstünlüğü metinlerden birinde beş, ikisinde yedi, altısında on madde hâlinde; geri kalan dokuzunda ise madde madde sıralanmadan ve belli bir sayı zikredilmeden verilmiştir. Ancak bunların tamamı dikkate alınıp birleştirildiğinde ilmin maldan üstünlüğüne dair hususların çoğaldığı görülür. Buradan hareketle, ilim ve malı 
eserlerinde konu eden müelliflerin hem başka eserlerden faydalanarak hem de kendi düşüncelerini, yorumlarını katarak yeni maddeler ekledikleri, bir anlamda konuyu genişletip geliştirdikleri, ilmin maldan üstünlügünü farklı açılardan görerek ifade etmeye çalıştıkları söylenebilir. Hemen belirtmek gerekir ki bunların bir kısmı birbirine yakın, birbiri içine geçmiş konulardır ve birlikte düşünülmelidirler. ${ }^{18}$

\section{Dört Şairin Dilinde İlim ve Mal}

İlim, ilim dalları, ilim öğrenmenin önemi ve yolları, hoca öğrenci münasebetleri gibi konular, klasik Türk edebiyatında şairlerin de sık sık üzerinde durdukları konulardandır. Şairler zaman zaman ayet, hadis ve vecizeleri de söz konusu ederek ilimle ilgili şiirler söylemişler, bazen bir beyitle bazen de bir gazel veya uzunca bir manzumeyle düşüncelerini nazma çekmişler, konuyla ilgili çeşitli tavsiyelerde bulunmuşlardır. ${ }^{19} \mathrm{Za}-$

${ }^{18}$ İlim çeşitli açılardan ele alınıp malla mukayese edilirken amelsiz ilmin faydasızlığı da özellikle vurgulanır. Sinan Paşa ilimle amelin bir arada olması durumunda bunun bir hazine, aksi takdirde ise bir eziyet olacağını dile getirir. Sünbülzâde Vehbî ise faydalı ilmin faydasız hâle gelmesini amelsizlikle açıklar:

'İlm ile olsa 'amel bir genc olur

Olmaz ise 'ilm kurı renc olur (Sinan Paşa) (Tulum 2001: 110)

Dahi ol 'ilm-i şerîf-i nâfi'

Bî-‘amel olmaya mahv u zâyi‘ (Sünbülzâdde Vehbî) (Beyzâdeoğlu 1996: 40)

Bu konuyla ilgili olarak "Faydasız ilimden Allah'a sığınırım." hadisi de hatırlanabilir. (Tirmizî, Daavât 69, 3478; Nesâî, İstiâze 2, [8, 255]) (Canan 1991: VII/107) Diğer taraftan ilim ve mal konularının mukayesesi sırasında ilmin maldan üstün tutulmasını, tercih edilmesini, vecizelerdeki gayeye uygun olarak ve metinlerdeki genel anlayış çerçevesinde faydalı ilimleri ögrenmek ve öğrenilmesine vesile olmak şeklinde anlamak; malın ve mal kazanmanın yerildiği şeklinde ya da bir reddetme olarak değil, üstün tutma, tercih etme şeklinde değerlendirmek icap eder. Buradan, insanların çalışıp mal mülk elde etmesinin, başkalarına da bu vesileyle faydalı olmasının bir sakıncasının olmadığı da kendiliğinden ortaya çıkmaktadır.

19 Ali Şîr Nevâî (öl. 902/1501), Lâmi‘î (öl. 938/1531), Celâl-zâde Sâlih Çelebi (öl. 962/1554), Fuzûlî (öl. 963/1556), Ulvî (öl. 993/1587), Cinânî (öl. 1004/1596), Gelibolulu Âlî (öl. 1008/1600) ve Ni'metî (öl. 1186/1772) gibi şairler, divanlarının dibacelerinde "ilim" ve "şiir" arasında sıkı bir ilişki olduğunu doğrudan veya dolaylı bir şekilde ifade etmişlerdir. Fuzûlî'nin Türkçe Divan'ının mukaddimesinde yer alan şu cümleler ise bu hususta dikkat çekicidir: "Bu hâle yaklaşınca, himmetimin gelin süsleyicisi, nazmımın güzelliğinin örtülü kadınlarının bilgi süsünden yoksun olarak dünya gelin sandalyesinde görünmesini uygun görmedi ve yüksek istidadımın sarrafı, şiir ipimin düğü- 
ten onlar, kendilerinde bulunan şiir söyleme istidatlarından başka, şairliklerinin bir yanını, en azından şiir için gerekli olan ilimleri öğrenmelerine borçludurlar. ${ }^{20}$

"Divan şiirindeki nitelemelere göre ilim, insanı diğer canlı varlıklardan üstün kılan, eşyanın hakikatini kavratan, her şeyin doğrusunu bildiren, doğru yolu gösteren, doğruyu yanlıştan, iyiyi kötüden ve güzeli çirkinden ayırmanın en güvenilir yolu olan, ahlakı güzelleştiren, insana kendi özünü bildiren, Hak'tan haber veren, nefsin isteklerini engelleyip günah sebeplerini ortadan kaldıran, cehaleti yok eden, iki âlemde de sahibine fayda sağlayıp onu ebedî mutluluğa kavuşturan üstün bir vasıf, büyük bir nimet ve yüce bir rehberdir." (...) "Divan şairleri, genel manada dinî veya tasavoufi bilgiyi ifade etmek, peygamberlere veya velilere Allah'tan vasitasız olarak ihsan edilen bilgiyi anlatmak, sahabelerin bilgi seviyelerini dile getirmek, bütün ilimleri toplu olarak belirtmek, dinî, tasavvufi, edeb̂̂ ve müspet ilimleri ayrı ayrı anmak, öğrenilmesini veya ilgilenilmesini istedikleri ilimleri beyan etmek, güzel ahlak şubelerini zikretmek ve ilmin niteliğini bildirmek için "ilm" kelimesi ile birçok terkip oluşturmuşlardır." (Güftâ 2004: 17-21). ${ }^{21}$

Daha önce de zikredildiği üzere ilim ve malla ilgili mukayesenin bazı eserlerde ayrıca yer almasının Hz. Ali'yle ilgili anlatılan bir hikâye-

münün ilim cevherinden mahrum bir şekilde âlemin boynuna bağlanmasına rıza göstermedi. Zira, ilimsiz şiir, temeli sağlam olmayan bir duvar gibi olur ve temelsiz duvar da gayet değersiz olur. Şiirimin derecesinin, ilim hırkasından soyunmuş olmasın ihanet sebebi bilip ve ilimsiz şiirden ruhsuz beden gibi nefret ederek bir müddet, hayatımın sermayesini aklî ve naklî ilimlerin inceliklerinin kazanılmasına sarf ettim ve ömrümün bütününü, felsefe ve matematikle ilgili lüzumlu şeylerin alınıp dă̆ıtılmasıyla geçirip hüner esnafının incilerinden nazım güzelime süsler düzenledim ve strasıyla tefsir ve hadis öğrenip şiirin faziletine $k l$ nama yakıştırmanın himmet eksikliği olduğu hakikatini bildim." (Üzgör 1990: 28, 277).

${ }^{20}$ Mehmet Kaplan, "Şiir ve İlim" başlıklı yazısında bütün divan şairlerinin devirlerinin ilim ve felsefesini bildiklerini, ancak çoğunun bunu eserlerinde bir süs olarak kullandığını söyler (Kaplan 1971: 3). Divan şairleri, genellikle düzenli ilim tahsili görmüş, dönemlerinin birçok ilmine vakıf, yüksek makamlarda görev yapmış kişilerdir. Oran olarak ilmiye sınıfına mensup şairler en büyük dilimi oluştururlar, onları bürokratlar takip eder. (bk.: Güftâ 2004: 421-432). Rindmeşrep bir yapıya sahip olan divan şairlerinin ilim ve mal konusuyla ilgili olarak vurgulanması gereken bir özelliği de soy, makam, mal ve mülkle değil; kitap, ilim, irfan, fazilet ve kemal ile övünmeleri, sahip oldukları mal mülkten bahsetmemeleri ve bunlarla övünmemeleridir (Güftâ 2004: 451).

${ }^{21}$ Eserde, "ilm" kelimesiyle kurulmuş tespit edilen 131 terkip verilmiştir. 
den dolayı özel bir nedeni vardır. Ancak şairler bunun dışında, yeri geldikçe ilim ve malı mukayese etmişler ve ilimle malın eşit olmadığı, ilmin maldan üstünlüğü, malın geçici, ilmin ise kalıcı olduğu, malın değil ilmin insan için bir iftihar vesilesi olabileceği, mal yığmanın, biriktirmenin faydasızlığı, asıl fakirliğin cehalet olduğu, malın mülkün kişiyi ilim tahsil etmekten alıkoyduğu... gibi hususları şiirlerinde sıkça dile getirmişlerdir. Eserlerde ilim ve malın ele alındığı birçok örnek bulmak mümkündür. ${ }^{22}$ Örneğin aşağıdaki beyitlerde ilmin üstünlüğü şöyle dile getirilir: ${ }^{23}$

Ol Emîrü'l-mü'minîn eytdi yine

Dünya mâlı dek degül Hak 'ilmine

Bu 'ilim yigrekdür ol mâldan bilüñ

‘İlme key renc yiñ ü key ragbet kıluñ (Âşık Paşa) (Yavuz 2000:

$I I / 2 / 747)$

Evet 'ilm efdal durur mâlden

İşit hâlden diyeyim kâlden (Bedr-i Dilşad) (Ceyhan 1997: II/540)

22 "İlim" ve "mal" söz konusu olduğunda ilimden yana bir tavır alınır. Ancak konu "aşk" olduğunda ilim aşkın yanında bir "kîl ü kâl"den ibaret kalır:

'İlm kesbiyle pâye-i rif'at

Ârzû-yı muhâl imiş ancak

Aşk imiş her ne var 'âlemde

'İlm bir kîl ü kâl imiş ancak (Fuzĥlî) (Akyüz vd. 1997: 306)

Şairler bazen aşkın kendisini de bir ilim, okunacak bir kitap ya da şerh edilip öğrenilecek bir metin olarak görürler. Şeyhî (öl. 835/1431?), aşk ilmini tahsil etmenin zorluğunu söylerken Ahmet Paşa (öl. 902/1496), aşk ilmini çok iyi tahsil ettiği ve âşıkları toplayıp onlara genel bir aşk dersi verse doğru olacağı iddiasındadır:

Tahsîl-i 'ilm-i 'aşkı âsân bilirdin evvel

‘Ömr âhir oldı olmaz hâsıl bu hoş hasâyil (Şeyhî) (İsen ve Kurnaz 1990: 206)

Fenn-i 'aşkı şöyle tahsîl itmişim mihrinle kim

Devşürüp 'uşşâkı bir gün ders-i âm itsem gerek(Ahmet Paşa)(Tarlan 1992a:200)

Aşk ve ilim ilişkisi hakkında daha geniş bilgi için bk. (Koçin 2003: 398-399)

${ }^{23}$ İlim ve malın mukayesesine dair gerek divanlarda ve mesnevilerde gerekse ilimden bahseden başka eserlerde çok fazla örnek bulmak mümkündür. Ancak burada sadece birkaçı zikredilip bütün bunların bir hülasası durumundaki ilim ve malın topluca mukayese edildiği dört şairin şiirleri üzerinde durulmuştur. Başka örnekler ve bazı değerlendirmeler için Hüseyin Güftâ (2004: 448-458) ve Âdem Ceyhan (2006: 375-376)'in eserlerine bakılabilir. 
'İlm efdaldür didi sen tutma şek

Pes ki mâldan 'ilmi yig bilmek gerek (Hazînî) (Avcı 2007: 100)

Var mıdır fâ'idesi dünyâda

Diseler de saña Vehbî-zâde

İrs olur mi eb ü ceddüñ hüneri

'İlmidür necl-i asîlüñ pederi

(...)

Mâl ile 'ilmi müsâvî sanma

Mâla ragbetle varup aldanma (Sünbülzâde Vehbî) (Beyzâdeoğlu

1996: 36)

Şeref virmez dür ü gevher kemâl olmaz zer ü zîver

Hüner kesb it hüner bahr-i fazîlet kân-1 'irfân ol (Bâkî)(Küçük

1994: 30)

Gel ey râhat sanan esbâb-ı cem' in kılma nâdânlıg

Tarîk-1 fakr tut kim fakr imiş 'âlemde sultânlıg

'İbâdet-i Hak u kesb-i 'ulûm için mutlak

Komaz mülâhaza-i zabt-i mâl bende mecâl (Fuzûlî) (Akyüz vd.: 1997 200, 307)

Ma'rifet ehline çün gencîne-i 'irfân yeter

Ey Usûlî gam degil olmazsa mülk ü mâllar (Usûlî)(İsen 1990:130)

Cehle beñzer cihânda fakr olmaz

Katı yohsul cihânda câhildür

Mâl ile nâkısı ganî sanma

Ol kişidür ganî ki kâmildür (Latîfî) (Canım 2000: 100)

14. asrın önemli siması Âşık Paşa'nın Garib-nâme adlı eserinde, "Bişinçi Dâsitân Onunçı Bâbdan Beyân İder Kim İlm Mâldan Efdaldür Bil Kim Hazret-i Risâlet Aleyhi's-Selâm Alî'ye Kerrema'llâhu Vechehu Buyurdı Ki 'Ene Medînetü'l-İlmi ve Aliyyün Bâbuhâ' Çün Havâric Bu Hadîsi İşitdiler Hased İttüp On Kişi İttifâk İtdiler Ki Alì'den Su'âl İdeler Ki İlm Efdal Midür Ya Mâl Bir Bir Varup Alî'ye Su'âl İtdükleri ve Cevâbın Beyân İder" başlıklı bölümde 154 beyitle (9479-9632. beyitler) ilmin maldan daha üstün olduğu Hz. Ali'ye nispet edilen hikâyeyle birlikte anlatılır. Âşık Paşa bu bölümdeki 
ilk beyitlerde Tanrı ilminin mutlaka öğrenilmesi gerektiği, ilim öğreneni halkın seveceği ve ona muhtaç olacağı, âlimin hem Tanrı hem de halk yanında büyük bir değerinin olduğu, dünyada ilmin de malın da tatlı olduğu, ancak ilim öğrenenin âlim ve fazıl, mal biriktirenin ise cimri olarak anılacağı gibi hususları beyitlerine taşır. İlmin maldan daha değerli olduğunu ifade ettikten sonra, "Ben ilim şehriyim, Ali de onun kapısıdır." hadisini verir, bunu bir beyitle de Türkçe olarak ifade eder:

Eytdi 'ilmüñ şehri benven kamusı

İlla bu şehrüñ 'Alî'dür kapusı (Âşık Paşa) (Yavuz 2000: II/2/743)

Âşık Paşa buradan sonra on kişinin gelip Hz. Ali'ye soru sormalarıyla ilgili yukarıda geçen hikâyeyi anlatır, ilmin maldan hangi açılardan ve ne şekilde üstün olduğunu izah eder. Hikâyeden sonra ise bu sözlerin gönüllerde yer ettiğini, dillerde dolaştığını, herkesin ilmin maldan üstün olduğunu gördüğünü, kişinin bilmediğini bilene sorması gerektiğini... anlatır, öğüt verir ve dua eder.

15. asırda Bedr-i Dilşad tarafından Keykâvus'un Kâbus-nâme adlı eserinden manzum olarak tercüme edilen ve II. Murad'a sunulan Muradnâme'nin "Der-Tafdîl-i İlm Ber-mâl" başlıklı bölümünde 34 beyitle (41234156. beyitler) ilim ve mal konusu ele alınır. Bedr-i Dilşad, tıpkı Kâbusnâme'de olduğu gibi, bahsi geçen hikâyeden söz etmeden ilmin maldan üstünlügünü yedi açıdan anlatır. Son üç beyitte ise Hâtime başlığı altında nasihat vardır ve bir sonraki bölüm olan cehalet konusuna geçileceği bildirilir.

Eserini tercüme ettiği yıla (930/1524) bakarak 15. asrın sonuyla 16. asrın başlarında yaşadığı tahmin edilen Hazînî'nin, Usfûrî'nin Şerh-i Hadîs-i Erbaîn adlı eserinden yaptığı manzum tercümesinde konu, eserin aslından hemen hemen farksızdır. Hazînî, ilim ve mal konusunu ilim öğrenmeyle ilgili dördüncü hadisten sonra "Hikâyet" başlığ1 altında 65 beyitle (297-361. beyitler) ele alır. O da tıpkı Âşık Paşa'da olduğu gibi konuyu hikâye formunda anlatır, ilimin maldan daha üstün olduğunu on farklı şekilde izah eder. Son beyit duaya ayrılmıştır. Hazînî'ye ait bu 65 beyitlik metin, ilim ve mal konusundaki vecizelerin çoğunluğunu ihtiva etmesi, bunları manzum bir hikâye şeklinde ilimle ilgili bir hadise isnat ederek derli toplu vermesi ve bir örnek olması bakımından yazının sonuna eklenmiştir. 
18. asrın şair ve bürokratı Sünbülzâde Vehbî, kendisinden bir asır önce yaşamış olan Nâbî (öl. 1124/1712)'nin Hayriyye'sinden etkilenerek oğlu Lutfullah için yazdığı Lutfiyye adlı eserinin "Der-Fezâil-i İlm-i Şerîf" başlıklı kısmında, ilmin maldan üstünlüğünü 26 beyitte (40-65. beyitler) kısaca anlatır. Vehbî, oğluna asaletin soy sopla değil hünerle, ilimle elde edilebileceğini, yükselmenin ancak ilim ve irfan sahiplerine nasip olacağını, âlim olmanın büyük bir mutluluk kaynağı olduğunu söyler, daha sonra da ilimle malın karşılaştırıldığı bazı beyitlere yer verir. Son kısımda ise ilmin vasıflarının çok olduğunu ancak hepsinin sayılmasının mümkün olmadığını belirtir.

Bu dört metinden Âşık Paşa ve Hazînî'ninki konuyu bir hikâye şeklinde anlatmaları bakımından diğer iki metinden ayrılır. Bu iki metinde konuya, Hz. Muhammed'in Hz. Ali'yi ilim şehrinin kapısı olarak nitelemesi ve on kişinin Hz. Ali'ye ilim ve malla ilgili soru sorma konusunda birleşmeleriyle başlanır:

Çün bularda var idi küfr ü nifâk

Pes bu kez on kişi kıldı ittifâk

Eytdiler görlüm 'Alî uşbu söze

Soralum bir ne cevâb eydür bize

24 Nihad Sâmi Banarlı, Resimli Türk Edebiyatı Târihi adlı eserinin 2. cildinde Sünbülzâde Vehbî'nin Lutfiyye'sinin Nâbî'nin Hayriyye'sine nazire olduğunu söyledikten sonra eserden alınmış üç beyitle birlikte şöyle bir değerlendirme yapar: "Meselâ her ikisi de çocuklarına ilim tahsîlini harâretle tavsiye ederler. Vehbî bu hususda biraz iğneli ve nükteli konuşur. (...) Bununla berâber, Vehbî'nin eserinde, Nâbî̀'de olduğu gibi, gençlere yüksek bir gaye, enerjik bir kalkınma yolu ve bir hamle ufku gösterilmez. Hattâ bu eserlere hâkim olan nasîhat, fazla yükseklere göz dikmeden, mütevâzî fakat menfaatçı bir insan olma ahlakı gibi görünür." (Banarlı 1998: II/782). Banarlı, buna sebep olarak da insanların Batı'daki fikrî ve sosyal hamlelerden habersiz olmalarını ve öyle yetişmelerini gösterir. Ancak yazarın eserle ilgili bu tespitlerinin isabetli olduğunu söylemek zordur. Belki toplumda, burada ifade edilen tarzda insanların olabileceği söylenebilir, ancak her iki eserde telkin edildiği iddia edilen mütevâzî fakat menfaatçı bir insan olma ahlakıyla ilgili ileri sürülen fikirler, Hayriyye ve Lutfiyye'nin genel yapısı, dönemin dinî, ahlaki ve kültürel anlayışı göz önüne alındığında akla yatkın değildir. Hatta Lutfiyye'nin medreselerde ve eski rüşdiyelerde o günün gençliğini terbiye için bir öğüt kitabı olarak okutulduğu düşülürse burada ileri sürülen fikirlere katılmak mümkün değildir. 
Onumuz bu sözi bir bir soralum

Mâl mi yigdür 'ilm mi yigdür görelüm (Âşık Paşa) (Yavuz 2000:

$I I / 2 / 745)$

Anlaruñ ulularından on kişi

Cem`oluban tanışurlar bu işi

Didiler buña soralum bir su'âl

Her birimüz ayru ayru bir mahâl

Cümlemüze ger virürse bir cevâb

Pes olur işi 'Alî'nüñ nâ-savâb

Yoksa her birümüze bir nev` ile

Ol cevâb aydup bizi râzî kıla

Mustafâ didügi gibi ol 'Alî

Pes kapusı ola 'ilmüñ ol velî (Hazînî) (Avcı 2007: 97-98)

$\mathrm{Bu}$ beyitlerden sonra hikâye, on kişinin birer birer gelip ilmin maldan üstünlüğüyle ilgili Hz. Ali'ye benzer ifadelerle aynı soruyu sormalariyla devam eder. Her bir soruya verilen farklı cevaplarda da yine birbirine benzeyen ifadeler vardır. Soru ve cevap kısımlarındaki bütünlük, ifade benzerliği ve on ayrı vecizeye bakarak şiirleri onar bölüm hâlinde düşünmek mümkündür. Âşık Paşa'da bu bölümler ortalama on birer beyit, Hazînî'de ise beşer beyittir. Âşık Paşa her bölümün sonunda, ilmin maldan üstün olduğunu, ilmin insanı Allah'a ileteceğini, malın ise buna engel olacağını,

Pes 'ilim yigdür bu mâldan mutlaka

Mâl girü kor şahsı 'ilm iltür Hak'a (Âşık Paşa) (Yavuz 2000:

II/2/747-765)

beytiyle aynen tekrarlar. Hazînî'de ise sistematik olarak tekrarlanan bir beyit yoktur, ancak şu üç beyit hemen hemen aynıdır:

Didi mâldan 'ilm efdaldür yakîn

‘İlmi efdal bilmegüñ yigdür hemîn

Didi yigdür 'ilmi yig bilgil yakîn

'İlmi yig bilmekligüñ yigdür hemîn 
Didi yigdür 'ilmi yig bilmek yakîn

‘İlmi yig bilmekligüñ yigdür hemîn (Hazîn̂̂) (Avcı 2007: 98-104)

Hikâyelerde dikkati çeken hususlardan biri, Hz. Ali'nin ilmin maldan üstün olduğunu söylemesi üzerine soru soranların, buna delil gösterilmesini, ilmin niçin tercih edilmesi gerektiğinin ispat edilmesini istemeleri ve bunun paralelinde ilmin üstünlüğüyle ilgili her bir hususun mantıklı bir temele dayandırılarak her bölümde oldukça açık bir şekilde anlatılmasıdır. Örneğin bahsedilen bu durum ikinci bölümde şöyle geçer:

Söz tamâm oldı vü gitdi ol kişi

Bu kezin geldi anuñ ol bir eşi

Ol dahı hem bu sözi kıldı su'âl

$\mathrm{Bu}$ 'ilim mi yigdür eytgil yohsa mâl

Ol Emîrü'l-mü'minîn eytdi yine

Dünya mâlı dek degül Hak 'ilmine (...)

Ol kişi sordı bu söze ne delîl Nite 'ilm oldı azîz ü mâl zelîl (...)

Ol ‘Alî eytdi ki mâlı her zamân İssi bekler issi olur pâsbân

$\mathrm{Bu}$ 'ilim oldur ki saklar issini

Diri dutar dîn ü hem dünyâsını (Âşık Paşa) (Yavuz 2000:II/2/747)

Ol bu söz ile rücû itdi revân

Geldi ikincisi anda ol zamân

Ol dahi ancılayın kıldı su'âl

Didi 'ilm efdal mi olur yoksa mâl

Didi 'ilm efdal durur mâldan hemân

Didi kim nedür delîlüñ kıl beyân

Didi sen mâla olursin pâsbân

‘İlm saña pâsbândur bil ayân (Hazînî) (Avcı 2007: 98-99) 
Âşık Paşa ve Hazînî'nin şiirlerindeki bazı hususlar bu şekildedir. Bedr-i Dilşad ve Sünbülzâde Vehbî'nin şiirleri de düşünüldüğünde ilim ve malın dört şair tarafından nasıl mukayese edildiğini, yukarıda verilen diğer metinlerden sonra ortaya çıkan başlıklardan da hareketle, maddeler hâlinde ve beyit beyit şöyle değerlendirmek mümkündür:

1. İlim peygamberlerin mirasıdır, mal ise Firavunların, eşkıyanın mirasıdır. Allah ilmi peygamberlere vermiştir, ilim onların sevgilisidir. Âlimler ise peygamberlerin varisleridir. Mal ise Nemrûd, Firavun, Hâmân, Şeddâd ve Kârûn gibilerinden kalmıştır, onların sevgilisidir. İlim yalnız mümine nasip olur, mal mümine ve kâfire nasip olur. Malı Allah sevdiğine de sevmediğine de, mümine de kâfire de verir. Ancak ilmi sadece sevdiklerine, müminlere verir:

Ol 'Aliyyi Murtazâ eytdi cevâb

‘İlmi ögrenmek kamu halka savâb

‘İlmi peygâmberlere virdi Celîl

Anuñ ile oldılar halka delîl

Mâlı Kârûn dirmiş idi bî-hisâb

Âkıbet anuñ ile oldı harâb (Âşı Paşa)(Yavuz 2000: II/2/745-747)

Didi ilm oldı mirâs-ı enbiyâ

Mâl Kârûn'dan kalupdur bî-hafâ

Hem dahi Hâmân u Şeddâd'dan durur

Dahi ol Fir'avn-1 bî-dâddan durur (Hazînî) (Avcl 2007: 98)

Enbiyâ' vârisi olmış 'ulemâ

Añla kim bu ne verâset ne ginâ' (Sünbülzâde Vehbî)

(Beyzâdeoğlu 1996: 36)

2. İlim, sahibini korur, oysa malı sahibi korur. İlim korumaya, bekçiye muhtaç değildir; malı ise beklemek, korumak lazımdır. Sahibi onu koruma düşüncesiyle, korkusuyla yaşar. Bilakis ilim sahibini korur, onu günah ve yasaklardan uzaklaştırır:

Ol 'Alî eytdi ki mâlı her zamân

İssi bekler issi olur pâsbân

$\mathrm{Bu}$ 'ilim oldur ki saklar issini

Diri dutar dîn ü hem dünyâsını (Âşık Paşa) (Yavuz 2000: II/2/747) 
Yidincisi oldur ki her bir kişi

Hemîn ‘ömri içinde budur işi

Ki mâlına dâyim nigeh-bân ola

Anuñ korkısıyla perîşân ola

Evet 'ilm issi nigeh-bânıdur

Ki cân 'ilme ten 'ilm anuñ cānıdur (Bedr-i Dilşad) (Ceyhan 1997:

Didi sen mâla olursın pâsbân

II/542)

‘İlm saña pâsbândur bil ayân (Hazînî) (Avcı 2007: 99)

3. İlim harcandıkça artar, mal harcandıkça azalır. Mal, vermekle azalır, ilim öğrenmekle ve öğretmekle, onu işledikçe, onunla amel ettikçe daha da artar. İlim, hazinelerden daha üstündür. Çünkü hazineler harcandıkça eksilir, ilimse harcanmakla çoğalır. Mal, Kaf Dağı kadar da olsa çabucak tükenir, ilim ne kadar çok harcansa o kadar artar. İlim yol üzerindeki kandil gibidir. Yoldan gidip gelenler onun ışığından istifade ederler, aydınlanırlar. Fakat kandilin ışı̆̆ı asla eksilmez:

Eytdi mâlı harc idiçek eksilür 'İlmi harc itdükçe artar açılur (Âşık Paşa) (Yavuz 2000: II/2/749)

Üçinci bu kim mâli isrâf ile Kaçan harcanurlarsa varur yile

Evet 'ilmi ne deñlü harc itseler Müdâm anuñ isrâfına gitseler

Kem olmaya belki ziyâde ola Ki her müstefîde ifâde ola (Bedr-i Dilşad) (Ceyhan 1997: II/541)

Didi mâldan viricek noksân olur Virdügine sâhibi pişmân olur Nice kim 'ilmi tasarruf itseler Karşu artar hûb olur iy mu'teber (Hazînî) (Avcı 2007: 100)

Kesr ü noksân viremez bezl ü seref Yokdur anda hatar-1 mahv u telef

Böyle sarf ile olur mi efzûn

Yere geçsün hele mâl-i Kârûn (Sünbülzâde Vehbî) (Beyzâdeoğ̆lu 
4. İlmi hırsızdan korumaya gerek yoktur, ama malı korumak gerekir. Mala hirsızdan, haramiden, yangindan ve buna benzer nesnelerden ziyan vardır, lakin akıl ve bilgiye ziyan yoktur. Mal gidince de sahibi mahrum olur. Malı hırsız ve harami alır ve telef eder, ilmi kimse ne çalabilir ne de zorla alabilir. Mal eşkıyadan saklanır, ilmi ise eşkıyadan saklamaya gerek yoktur:

Eytdi mâlı ugrı alur añsuzın

Hem harâmî urur iltür geñsüzin

Lîki bu 'ilmi kimesne alımaz

Hükm idüben kimse hâkim olımaz (Âşık Paşa) (Yavuz 2000:

$I I / 2 / 751)$

Didi mâlı dâ'im ugrı aparur

Mâl gidicek iyesi mahrûm kalur

Ugrı aslâ 'ilme hîç kâr eylemez

‘İlm iyesi ugrilardan gam yimez (Hazînî) (Avcr 2007: 101)

Cebr ile hâkim ü vâlî alamaz

Kalsa meydânda hırsız çalamaz (Sünbülzâde Vehbî)

(Beyzâdeoğlu 1996: 37)

5. İlim sahibi asla unutulmaz, ilmi kendisindedir; fakat mal sahibi unutulur gider, mal başkalarına kalır. Mal sahipleri malın zevaliyle zeval bulup giderler. İlim âlime yaşarken taat kazandırır, öldükten sonra hayırla anılmasını sağlar. Mal biriktiren ise malla birlikte yok olur, adı da kalmaz. Mal yığanlar diriyken bile ölü gibidirler. Ulemanın ise dünya durdukça adı anılır. Âlimler ölüp gider, ama menkıbeleri gönüllerde yaşar. İlim ancak, ona sahip olanların ölüp tamamen yok olmasılla ortadan kalkar. Mal cahilin elinden çıkar gider, ama akıl ve bilgi kişiden gitmez. İlim sahipleri ölmezler, kıyamete kadar da amelleri kesilmez, ebedî olarak ilmi kendileri ile beraber gider. Mal sahibi ise ölür, ameli kesilir, malı başkalarına kalır:

Yigligi şoldur kişi çün kim ölür

Mâlını vü mülkini ayrug alur

'İlmini alur gider anda bile

Nitekim bundayıdı anda bile (Âşık Paşa) (Yavuz 2000: II/2/753)

Dâr-1 'ukbâya ber-â-berce gider

Hem cihânda biragur nice eser (Sünbülzâde Vehb̂̂)

(Beyzâdeoğlu 1996: 37) 
6. İlimle mal elde edilir, ancak malla ilim elde edilmez. Akıl ve bilgiyle mal hasıl edilebilir, lakin mal ile akıl ve bilgi hasıl etmek mümkün olmaz. Âlimin hiç malı olmasa ilim vesilesiyle mal elde edebilir, ama malı olup ilmi ve kifayeti olmayanın malla ilim elde etmesi mümkün değildir. Malla sadece bu dünyanın nimeti elde edilebilir, ancak ilimle her ikisi elde edilir, insan her ikisinde de mutlu olur. Ayrica ilim olmadan kazanulan malın da bir değeri yoktur:

Ol 'Alî eytdi ‘ilim yig nesnedür

‘İlme baksañ nişe gelür mâl nedür

Kimse kim cehd itdi 'ilm ögrenmege

Hîç gümânsuz irdi ol mâldan yige

(...)

Eytdi mâl birle bu dünyâ ni'meti

Hâsıl olur şahsa dünyâ 'izzeti

'İlm ile dünyâ vü 'ukbâ alınur

İkisinden 'izz ü devlet bulınur (Âşık Paşa) (Yavuz 2000: II/2/755)

Hem altıncı bu 'âlim olsa fakîr

Ganîler gözine görinse hakîr

Elinden gelür mâl tahsîl ide

Gınâsına fakrını tebdîl ide

Evet bir kişi mâldâr olsa key

Ki her nev'a emvâli var olsa key

Fakîr olsa 'ilm ü kifâyetde ol

Bilide hakîr ise gâyetde ol

Ne mümkin ki tahsîl-i 'ilm eyleye

Ki Hak'dan nasîbini hilm eyleye (Bedr-i Dilşad) (Ceyhan 1997:

II/541-542)

7. Ilim kalbi nurlandirır, mal ise kalbi karartır. İlim, sahibine sirayet eden bir nurdur. Mal kalbe kasvet verir, kalbi karartır, ilim ise kalbi ferahlatır, aydınlatır. Mal kalbin katılaşmasına sebep olur, ilim rahmete sebep olur. İlim ruhun gidasıdır, mal ise cesedin gidasıdır. Mal sevgisi insanı yine mal sevgisine götürür, yani daha çok mal kazanma ve biriktirme hirsina sevk eder: 
Eytdi mâl sevgüsi çün mâla konar

Endişeyle kişinüñ göñli tunar

Cân göñül bu 'ilm ile rûşen olur

Bakdug1 yir gözine gülşen olur (Âşık Paşa) (Yavuz 2000: II/2/757)

Didi mâl kalbi kara eyler yakîn

Dilleri pür-nûr ider 'ilm iy emîn (Hazînî) (Avcl 2007: 103)

8. İlim sahibi kıyamet günü şefaat edecek, mal sahibi ise hesaba çekilecektir. Kıyamet gününde ilmin hesabı yoktur. Fakat malın helal ise hesabı, haram ise azabı vardır. İlim sahibi kabirde azaba uğramaz, cesedi çürümez. Mal sahibi ise kabirde azaba uğrar, cesedi çürür. Mal sahibi kıyamet gününde her bir dirhemi nereden kazanıp nereye harcadığından sorguya çekilecektir. Yalnız başına ilim tatsız da olsa kurtuluşa vesiledir, mal ise azaba sebep olur. İlim sahibi şefaat edecek, mal sahibi şefaat edilecektir:

Eytdi mâl issi helâl içün hisâb

Vire, göre hem harâm içün 'azâb

İlla 'âlimler şefâ'atçı ola

Yarın anda suçluyı elden ala (Âşı Paşa) (Yavuz 2000: II/2/759)

Bişinci bu kişi idincek vefât

Bulur 'ilm ucından sakardan necât

Evet mâl ucından çekilür 'ikâb

Harâma 'azâb u helâla hisâb (Bedr-i Dilşad) (Ceyhan 1997: II/541)

Didi ki mahşer güni mâl yıganuñ

Cümle isterler hisâbını anuñ

'İlm ehli niceye olur şefî‘

Nicelerüñ menzilin eyler refî‘ (Hazînî) (Avcı 2007: 102)

9. İlim Allah'ın kelamından, mal ise topraktan çıkar. İlmin kaynağı Allah'tır, insanlara ilmi Allah öğretmiştir. Malın aslı ise yerdir, yerden çımıştır, yine yere gidecek, orada yok olacaktır. Bu yüzden ilmin değeriyle malın değeri bir değildir:

Her kimüñ kim 'ilmi çoksa baydur ol

Kamular yılduz gibidür aydur ol

(...) 
'İlmi gökden viribidi ol Celîl

İssini iltdi göge oldı delîl

Mâluñ aslı yir durur yirden biter

Kim anı sevdiyse bu yirde yiter (Âşık Paşa) (Yavuz 2000: II/2/761)

10. İlim sahibi Allah'a kul olur, mal sahibi ise ilahlik davasinda bulunur. Mal sahibi, çok malı sebebiyle isyan eder, büyüklük taslar, malına güvenerek ilahlık davasında bulunur. İlim sahibi ise iyi bir kul olmaya çalışır, işi zikir ve taattir, tevazu sahibidir. İlim kişiyi ahirete, mal dünyaya meylettirir. İlim insanı Allah'a ulaştırır, mal ise onu geri kor. İlim, sahibine sıratı geçmekte yardım eder, huzura kavuşmaya vesiledir. Mal ise sahibini sıratı geçmekten men eder:

Pes ilim yigdür bu mâldan mutlaka

Mâl girü kor şahsı ilm iltür Hak'a

Didi ‘ilmüñ yigligi şoldur i yâr 'İlmi olan Tanri'nuñ emrin tuyar

Mâlı olan ne bilür Hak emrini Ma'siyetde geçürür ol ‘ömrini (...)

Eytdi şol ma‘nîyile kim 'ilmi çok Tañrılık da'vîsini itdügi yok Zikr ü tâ'atdur hemîşe işleri Andan artuk yok durur teşvîşleri İlla her kim mâlı çok oldı bular Tañrılık da'vîsini kıldı bular Bunları başdan çıkardı mâlları Ol sebebden azgun oldı hâlları (Âşık Paşa) (Yavuz 2000:

Mâllu olan kişi göñli ulalur Hem rubûbiyyetden ol da'vî kılur (...)

Ehl-i 'ilm olur tevâzu'da müdâm Virdi anlaruñ cevâbını tamâm (Hazînî) (Avcı 2007: 104) 
11. İlim hâkimdir, malsa hüküm altındadır, mağluptur. İlim padişah gibi hâkimdir, mal raiyet gibi mahkûmdur. Sultanla raiyet arasındaki fark ne miktarsa ilimle mal arasındaki fark da o kadardır. Padişahlar halk üzerinde hâkimdirler, ama âlimler ilimleriyle padişahların da üstündedirler. Şimdiye kadar padişahlar ilim ehlini muteber ve muhterem tutmuşlar, onlara riayet etmeyi kendileri için uygun görmüşler, birçok işte ilim sahiplerine muhtaç olmuşlar ve onların söylediklerini başlarına taç yapmişlar, kurtuluşun ilimle olduğunu görmüşlerdir. Ancak mal sahipleri malların korumak, ellerinde tutabilmek için padişahlara, onların beylerine, hatta beylerin hizmetkârlarına hizmet etmek zorunda kalmışlardır:

Biri ol ki 'ilm ehli olanlara

Husûsâ ki hilm ehli olanlara

Şehenşâh olanlar ider iltifāt

Bilür 'ilm iledür belâdan necât

Nice işde anlara muhtâc olur

Ne dirse sözi başına tâc olur

Evet mâl ehli bunuñ 'aksine

Olur hod bilürsin dime 'aksi ne

Bular belki mâlin sakınmag içün

Selâmet adını dakınmag içün

Şehenşâha kendüyi hâdim ider

Anuñ ile mâlini sâlim ider (Bedr-i Dilşad) (Ceyhan 1997: II/540)

12. İlim durmakla zayi olmaz, mal durmakla zayi olur. Mal zamanla yok olur, bazen de birden elden çıar, kişi iflas eder, içten içe onu haset yer, ilim ise yok olmaz. Ayrıca mal bir süre durduğunda çürür, zarar görür; ilme ise yüzyıl dursa, dünya yansa, suya gark olsa bir şey olmaz:

O dördinci bu kim helâk olsa mâl

Harâm ola aslında yâhûd helâl

Hemân issi müflis olur bî-meded

Bu kez od gibi yir içinden hased

Evet 'ilme hergiz fenâ yok durur

Bekâ bilür iseñ bekâ çok durur (Bedr-i Dilşad)(Ceyhan 1997: II/541)

Didi tursa mâl bir nice zamân

Çürüyüp tebdîl olur bilgil 'ayân 
Çürümez 'ilm ebter olmaz bellü bil

Ol eger tursa nice yüz kerre yıl (Hazînî) (Avcı 2007: 102)

Agniyâ müflis olur bir demde

Görmüşüz nicesini 'âlemde

$(\ldots)$

'Ulemâ çekse de farzâ hüsrân

'İlm sermâyesi bulmaz noksân

Âteşe yansa cihân hark olmaz

Kopsa tûfân suya gark olmaz (Sünbülzâde Vehbî) (Beyzâdeoğlu

13. İlim sahibinin dostu, mal sahibinin düşmanı çoktur. İlim, sahibini her türlü afetten korur, mal ise afete, belaya sebep olur. Mal yüzünden kişi dünyada ve ahirette belalardan kurtulmaz, başları ve canları mal yüzünden tehlike içindedir. Her zaman huzursuzdurlar, asayiş içinde değillerdir. Ulema, ilim vesilesiyle çoğu tehlikelerden ve belalardan korunmuş kutlu insanlardır. Korku anlarında ilim, sahibine arkadaştır. Mal ise aksine korku, ürküntü verir. Yolculuk sırasında ilim insanın arkadaşıdır, mal ise yolculukta kişinin düşmanı olur. Mal sahibinin birçok düşmanı vardır, ilim sahibinin ise pek çok dostu vardır. İlim sayesinde düşmanlar dost olur, fakat mal böyle değildir:

İkinci bu 'ilm ehli ‘ilmiyile

Tevâzu'larıyile hilmiyile

Belâlardan iymin olurlar müdâm

Cihânuñ içinde oluban hümâm

Evet çokdur âfâtı mâl ehlinüñ

Belâdur mükâfâtı mâl ehlinüñ

Nicesi olur mâl ucından helâk

Ki dehşet ider zehrelerini çâk

Hakîkatde yası sanurlar dügin

Kogil gice gündüz belâ çekdügin (Bedr-i Dilşad)(Ceyhan II/540-541)

Dir 'Alî mâldâr olanuñ dünyede

Çok olur düşmânı bilgil iy dede

Çok olur dünyâda 'ilm ehline yâr

Kim anı görse özine dôst tutar (Hazînî) (Avcı 2007: 99) 
Mâl bir nesne ki çok düşmeni var

Yolını bekleyici reh-zeni var

'İlm ile sîneñi eyle mâlî

Saklasun mahzene herkes mâlı (Sünbülzâde Vehbî)

(Beyzâdeoğlu 1996: 37)

14. İlim sahibini âlim, fazıl diye, mal sahibini ise cimri diye çă̆̆tırlar. Mal sahibinin her ne kadar adı zengin, bey de olsa cimrilik ve alçaklıkla, ilim sahibi ise azamet ve şerefle anılır. Âlimin hem Allah'ın yanında hem de halkın yanında değeri vardır:

Gerçi mâldâr adı bay u beg durur

İlla mâldan bu 'ilim çok yig durur

‘Âlimüñ çün halk katında sadrı var

Hem dahı Hak hazretinde kadrı var

(...)

Dünyada 'ilmüñ ve mâluñ dadı var

Bunları kim çok direrse adı var

Birnüñ adı 'âlim ü fâzıl durur

Birnüñ adı nâkes ü müdhil durur (Âşı Paşa)(Yavuz 2000:II/2/741)

Dir 'Alî bu söze isterseñ delîl

Mâl yıganı dâ'im okurlar bahîl

'İlm iyesine velî dirler kerîm

Dâ'im aña tahsîn eylerler 'azîm (Hazînî) (Avcı 2007: 101)

\section{Sonuç}

Temeli Hz. Ali'nin söylediği sözlere dayandırılan ilim ve malın mukayesesine dair vecizeler, geçmişten günümüze birçok eserde müelliflerin sıkça sözünü ettikleri bir konu olmuştur. 11. asırdan 19. asra kadar tespit edilebilmiş on dördü mensur dördü ise manzum toplam on sekiz metinde müelliflerin ilim ve mal konusunda zikrettikleri vecizelerin bir kısmı birbiriyle hemen hemen aynıyken bir kısmı gerek ifade gerekse içerik olarak farklılık gösterir. Bazı metinlerde ilmin maldan üstün olduğuna dair beş ya da yedi farklı husus varken bazılarında on ayrı üstünlük zikredilmiştir. Ancak bu metinlerin hepsi bir bütün olarak düşünüldüğünde, ilmin maldan üstünlüğüyle ilgili hususların ondan daha fazla olduğu ortaya çıkmaktadır. Müelliflerin, hem başka eserlerden faydala- 
narak hem de kendi düşüncelerini katarak ilmin üstünlüğüne dair hususları çoğalttıkları anlaşılmaktadır. Her ne kadar ayrı başlıklar altında verilmişlerse de bunların aynı konunun birer parçası olduğunu unutmamak gerekir. Klasik Türk edebiyatının önde gelen bazı temsilcileri de gerek mesnevilerde ayrı bir başlıkla gerekse divanlarda bir gazel ya da birkaç beyitle ilim ve mal konusuna değinmişlerdir. 14. asırdan Âşık Paşa, 15. asırdan Bedr-i Dilşad, 16. asırdan Hazînî ve 18. asırdan Sünbülzâde Vehbî doğrudan doğruya bu konuyu eserlerine taşıyan şairlerdendir. Bu şairlerin eserlerindeki genel çerçeve, mala karşı ilmin üstünlüğü ön planda olsa da, ilmin değeri ve ilim tahsil etmenin önemidir. Şairler de şairlikleri için gerekli olan ilimleri tahsil etmeleri ve ilim konusunu malla mukayese ederek tercihlerini ilimden yana kullanmalarıla bunu vurgulamış olmaktadırlar.

\section{Kaynaklar}

Akyüz, Kenan-Süheyl Beken-Sedit Yüksel-Müjgan Cunbur (1997), Fuzûlî Divanı, Ankara: Akçă̆ Yay.

Arat, Reşid Rahmeti (1992), Edib Ahmed B. Mahmud Yükneki Atabetü'l-Hakayık, Ankara: TDK Yay.

Arat, Reşid Rahmeti (1997), Kutadgu Bilig I Metin, Ankara: TDK Yay.

Arslan, Yakup (2007), Mümeyyiz Dergisi'ndeki Dinî Motiflerin Din Eğitimi Açısından İncelenmesi, Basılmamış YLT, Marmara Üniversitesi SBE, İstanbul.

Avc1, İsmail (2007), Hazîn̂̀'nin Manzum Şerh-i Hadîs-i Erbaîn Tercümesi, Basılmamış YLT, Balıkesir Üniversitesi SBE, Balıkesir.

Ayan, Gönül (1996), Tebrizli Ahmedî Esrâr-Nâme, Ankara: AKM Yay.

Aynî, Mehmet Ali (1993), Türk Ahlakçıları, İstanbul: Kitabevi Yay.

Banarlı, Nihad Sâmi (1998), Resimli Türk Edebiyatı Târihi, Cilt II, İstanbul: MEB Yay.

Beyzâdeoğlu, Süreyya Ali (1996), Sünbülzâde Vehbî Lutfiyye, İstanbul: Cihan Neşriyat.

Birlik, Dilek (2001), Bâlı̂'nin Bahru'n-Nasâyih'i, Giriş-Transkripsiyonlu MetinDizin, Basılmamış YLT, Marmara Üniversitesi Türkiyat Araştırmaları Enstitüsü, İstanbul.

Canan, İbrahim (1991), Kütüb-i Sitte Muhtasar Tercüme ve Şerhi, Cilt VII, XI, XV, Ankara: Akçağ Yay. 
Canım, Rıdvan (2000), Latîfî, Tezkiretü'ş-Şu'arâ ve Tabsıratü'n-Nuzamâ, Ankara: AKM Yay.

Ceyhan, Âdem (1997), Bedr-i Dilşad'ın Murâd-nâmesi, 2 Cilt, İstanbul: MEB Yay.

Ceyhan, Âdem (2006), Türk Edebiyatı'nda Hazret-i Ali Vecizeleri, Ankara: Öncü Kitap.

Ceyhan, Âdem (2008), Reşîüuddin Vatvat, Hazret-i Ali'nin Yüz Sözü Gül-i SadBerg, çev.: Hocazâde Abdülaziz Efendi, İstanbul: Buhara Yay.

Doğan, Ahmet (2002), Kuddûsî Divanı, Ankara: Akçă̆ Yay.

Durak, Hasan Hüseyin (2002), Usfûrî'nin Kırk Hadis Şerhi'nin Tahkîk, Tahrîc, Terceme ve Tenkidi, Basılmamış YLT, Uludağ Üniversitesi SBE, Bursa.

Er, Âdem (1998), Bâlı̂ Çelebi'nin Bahru'n-Nasâyıh Adlı Eseri Üzerinde Bir Gramer Araştırması (Fonetik, Morfoloji, Sentaks, Metin, Lügat), Basılmamış YLT, Selçuk Üniversitesi SBE, Konya.

ez-Zernûcî, İmam Burhanüddin (1996), Ta'limü'l-Müteallim, trc.: Ziya Eryılmaz, İstanbul.

Gazâlî (1998), İhyâu Ulûmi'd-Dîn, Cilt I, çev. Sıtkı Gülle, İstanbul: Huzur Yay. Gökyay, Orhan Şaik (2006), Keykâvus, Kabusnâme, çev.: Mercimek Ahmed, İstanbul: Kabalcı Yay.

Gölpınarlı, Abdülbaki (trz), Hazret-i Ali, Nehcü'l-Belâga, İstanbul: Der Yay.

Güftâ, Hüseyin (2002), "Divan Şiirinde İlim ve İrfan Timsâli Hz. Ali”, Hacı Bektaş Veli Dergisi, Sayı 24, s. 69-111.

Güftâ, Hüseyin (2004), Divan Şiirinde İlim, Ankara: Akçağ Yay.

İmam-1 Gazâlî (2007), Mişkâtü'l-Envâr, trc.: Şadi Eren, İstanbul: Nesil Yay.

İnce, Adnan (2000), Cem Sultan Cemşî̀d ü Hurşî́d, Ankara: TDK Yay.

İsen, Mustafa (1990), Usûlî Divanı, Ankara: Akçă̆ Yay.

İsen, Mustafa-Cemâl Kurnaz (1990), Şeyhî Divanı, Ankara: Akçağ Yay.

Kaplan, Mahmut (2008), Hayriyye-i Nâbî, Ankara: AKM Yay.

Kaplan, Mehmet (1971), "Şiir ve İlim”, Hisar, Sayı 94, s. 3-4.

Kargılı, Abdullah-Osman Yolcuoğlu (2005), A. Şemseddin Sivasî, Dört Halifenin Menkıbeleri (Menâkıb-ı Çehâr-Yâr-i Güzîn), İstanbul: Sufi Kitap.

Kılıç, Atabey (2005), Mürîdî ve Pend-i Ricâl Mesnevîsi, İzmir: Akademi Kitabevi.

Koçin, Abdülhakim (2003), "Divân Şiirinde Şairlerin Aşka Yaklaşımları", Kastamonu Ĕ̆itim Dergisi, Cilt 11, Sayı 2, s. 395-422. 
Kutluer, İlhan (2000), “İlim”, DİA, Cilt XXII, İstanbul: Türkiye Diyanet Vakfı Yay.

Kutluer, İlhan (2001), İlim ve Hikmetin Aydınlı̆̆ında, İstanbul: İz Yay.

Küçük, Sabahattin (1994), Bâkî Dîvânı, Ankara: TDK yay.

Minhâcü'l-Müteallim (trz), çev.: Yunus Vehbi Yavuz, Mudanya: Feyiz Yay.

Özfırat, Bayram (2006), Tokatlı İshâk Efendi'nin Nazmu'l-Ulûm, Nazmu'l-Le'âlî ve Manzûme-i Keydânî Adlı Mesnevileri, Basılmamış YLT, Selçuk Üniversitesi SBE, Konya.

Özkan, Abdurrahman (2009), Mehekkü'l-ìlim ve'l-Ulemâ, Isparta: Fakülte Kitabevi.

Özkan, Mustafa (1990), Cinân̂̂ Cilâ'ü̈l-Kulûb, İstanbul: İstanbul Üniversitesi Yay.

Sahabeden Günümüze Allah Dostları I, Hilyetü'l-Evliyâ, Ebu Nuaym el-Isfahân̂,, Sıfatü's-Safve, İbnü'l-Cevzî (1995), çev.: Said Aykut-Enver GünençYahya Atak-Abdülhamid Birışık-Fuat Aydın, İstanbul: Şûle Yay.

Şeker, Mehmet (2002), Ali b. Hüseyin el-Amâsî ve Tarîku'l-Edeb'i, Ankara: Diyanet İşleri Başkanlığı Yay.

Tarlan, Ali Nihat (1992a), Ahmet Paşa Divanı, Ankara: Akçağ Yay.

Tarlan, Ali Nihat (1992b), Hayâlî Bey Dîvâni, Ankara: Akçağ Yay.

Taşköprülüzâde Ahmed Efendi (1975), Mevzûâtü'l-Ulûm (İlimler Ansiklopedisi), trc.: Taşköprülüzâde Kemâl Efendi, sdl.: Mümin Çevik, Cilt I, İstanbul: Üçdal Neşriyat.

Tatçı, Mustafa (1997), Yûnus Emre Dîvânı II, İstanbul: MEB Yay.

Tulum, A. Mertol (2001), Tazarru'nâme, Ankara: MEB Yay.

Üzgör, Tahir (1990), Türkçe Dîvân Dîbâceleri, Ankara: Kültür Bakanlığı Yay.

Yağmur, Ömer (2007), Terceme-i Kitâb-ı Fevâ'ihü'l-Miskiyye fi'l-Fevâtihi'lMekkiyye, Basılmamış YLT, İstanbul Üniversitesi SBE, İstanbul.

Yavuz, Kemal (2000), Âşık Paşa, Garib-nâme, II/2, İstanbul: TDK Yay.

Yavuzarslan, Paşa (2002), Mûsâ bin Hâcı Hüseyin el-İznikî, Münebbihü'r-Râkidîn (Uyurları Uyanduruct), Giriş-İnceleme-Tenkitli Metin, Cilt I, Ankara: TDK Yay.

Yılmaz, Mehmet (2008), Kültürümüzde Arapça ve Farsça Asıllı Vecizeler Sözlü̈̆̈ü, Cilt II, İzmir: Sütun Yay. 


\section{HİKĀYET \\ [HAZÎNÎ, MANZUM ŞERH-i HADÎS-İ ERBAÎN TERCÜMESİ]}

Bir ḥikāyet diñle imdi ṣıdk ile Bu hadis üste getüreyüm dile

Mușțafā didi ki 'ilmüñ şehriven Kapusıdur ol 'Aliyyü Bü'l-Hasan

Çün Havāricler işitdi bu sözi Fikre batdılar gicesi gündüzi

300 Pes 'Alī'ye eyledi anlar hased Ol hadisisi itmek isterlerdi red

Anlaruñ ulularından on kişi Cem`oluban țanışurlar bu işi

Didiler buña șoralum bir su'āl Her birimüz ayru ayru bir maḥāl

Cümlemüze ger virürse bir cevāb Pes olur işi 'Alì'nüñ nā-ṣavāb

Yoḳsa her birümüze bir nev' ile Ol cevāb aydup bizi rāżi ḳıla

305 Muștafā didügi gibi ol 'Alī

Pes ḳapusı ola 'ilmüñ ol velī

Geldi anlaruñ biri ḳıldı su’āl Yā 'Alì dir 'ilm mi yigdür yoḳsa māl

Didi māldan 'ilm efḍaldür yakīin '̇̇mi efḍal bilmegüñ yigdür hemīn
Didi yigligi nedendür söylegil

Gel dil ile anı taḳrīr eylegil

Didi 'ilm oldı mīrās-1 enbiyā'

Māl Ḳārūn'dan ḳalupdur bì-ḩafā'

310 Hem dahi Hāmān u Şeddād'dan durur Dahi ol Fir'avn-1 bī-dāddan durur

Ol bu söz ile rücū' itdi revān

Geldi ikincisi anda ol zamān

Ol dahi ancılayın ḳıldı su'āl

Didi ilm efụal mi olur yoḳsa māl

Didi ilm efḍal durur māldan hemān

Didi kim nedür delīiüñ ḳıl beyān

Didi sen māla olursın pāsbān 'İlm saña pāsbāndur bil 'ayān

315 Bu cevābı aldı gitdi ol dahi

Geldi üçincisi ol dem iy ahī

Anlaruñ tek ol dahi ḳıldı hițāb 'İlm efḍaldür diyü virdi cevāb

Dir delīiüñ bu söze nedür digil Bunı sen taḳrīi idüp şerh eylegil

Dir 'Alī māldār olanuñ dünyede Çoḳ olur düşmānı bilgil iy dede 
Çoḳ olur dünyāda 'ilm ehline yār Kim anı görse özine dōst țutar

320 Gitdi ol dördincisi geldi revān Ṣordı ol da anlaruñ tek der-zamān

Didi ki 'ilm ile māldan söylegil Kanḳısı efḍal durur şerh eylegil

'İlm efḍaldür didi sen țutma şek Pes ki māldan 'ilmi yig bilmek gerek

Didi ki nedür delīlüñ bu söze Anı bildür tīz 'ayān eyle bize

Didi māldan viricek noḳsān olur Virdügine șāhibi pişmān olur

325 Nice kim 'ilmi tașarruf itseler Karşu artar hūb olur iy mu'teber

Gitdi ol dah ol cevāb ile o dem Geldi bişincisi dahi șordı hem

Söylegil 'ilm ile mālı iy 'Alì Kanḳı efḍaldür beyān it iy velī

Dir 'Alì kim 'ilm māldan yig olur 'Aḳlı olan bu sözüñ remzin bilür

Dahi hem aydur delīlüñ söylegil Yigligini bize ma'lūm eylegil

330 Dir 'Alī bu söze isterseñ delīl Māl yıġanı dā'im oḳurlar bahīi

'ìlm iyesine veli dirler kerīm Dā'im aña taḥsīn eylerler 'azīim

Gitdi ol dahi o söz ile tamām Geldi altıncısı ṣordı iy hümām
Anlaruñ tek virdi aña dah cevāb Didi ki göster delīlüñ bā-ṣavāb

Didi mālı dā’im uğrı aparur Māl gidicek iyesi maḥrūm ḳalur

335 Ug̉rı aṣlā 'ilme hīç kār eylemez '̇lm iyesi uǵrılardan gam yimez

Gitdi ol geldi yidincisi durar '̇lm yig mi yoḳsa māl mı dir șorar

Didi yigdür 'ilmi yig bilgil yaḳin '̇lmi yig bilmekligüñ yigdür hemīn

Didi bu söze delīl göster baña Tā ki ben varam işüme bā-ṣafā

Didi ki maḥşer güni māl yıġanuñ Cümle isterler hisābını anuñ

340 'İlm ehli niceye olur şefí $\bar{i}^{c}$ Nicelerüñ menzilin eyler refí $\bar{i}^{c}$ Geldi sekizinci çünki gitdi ol Ol dahi șordı yine iy pür-uṣūl 'İlm efḍal mi olur dir yoḳsa māl Dir 'Alì ki 'ilm yigdür itme ḳāl

Didi göstergil delīl eyle temiz Anı işidüp gidem ben tiz-be-tīz

Didi țursa māl bir nice zamān Çürüyüp tebdīl olur bilgil ‘ayān

345 Çürümez 'ilm ebter olmaz bellü bil $\mathrm{Ol}$ eger țursa nice yüz kerre yıl Gitdi ol geldi țoḳuzıncı revān Yā 'Alì dir eylegil bu dem beyān 
'İlm māluñ ḳanḳısı efḍal durur Eyle tafșil bu baña mücmel durur

'İlmi yigdür didi māldan lā-muhāl Mālı yig bilmeklige yoḳdur mecāl

Dir delīlüñ var midur söyle baña Tā ki ben muțịi olam cāndan saña

350 Didi māl ḳalbi ḳara eyler yaḳin Dilleri pür-nūr ider 'ilm iy emīn

Gitdi ol geldi onıncısı revān Anlaruñ tek șordı ol dahi hemān İmdi virgil 'ilm ile māldan ḩaber Kanḳısı efḍal durur iy mu'teber 'İlm efḍaldür didi aña 'Ali Dir delīiüñ var mı durur iy veli Māllu olan kişi göñli ulalur Hem rubūbiyyetden ol da'vī ḳılur
355 Didi yigdür 'ilmi yig bilmek yaḳin 'İlmi yig bilmekligüñ yigdür hemīn

Didi bu söze delīl göster baña Tā ki ben varam işüme bā-ṣafā

Ehl-i 'ilm olur tevāżu'da müdām Virdi anlaruñ cevābını tamām

Anlara didi 'Alī iy merdümān Bilüñüz kim 'ömrüm olduḳca hemān Șorsañuz bu nev' ile min-külli bāb Her biriñüze virürem bir cevāb

360 Çünki anlar bunı böyle bildiler Cümlesi țurup īmāna geldiler

Ehl-i 'ilmüñ hürrmetine iy Hudā Bì-nașīb itme bizi yevmü'l-cezā' 